\title{
Okul öncesi fen ve doğa eğitimi araştırmalarına ilişkin bir tarama çalışması: Türkiye örneği
}

\author{
A screening study about preschool science education studies: A case \\ study from Turkey
}

\author{
Gökhan Güneş ${ }^{1}$
}

\section{Makale Geçmişi \\ Geliş : 27 Kasım 2017 \\ Düzeltme : 25 Aralık 2017 \\ Kabul : 03 Ocak 2018 \\ Çevrimiçi : 07 Ocak 2018 \\ Makale Türü \\ Özgün Makale}

\section{Atticle History}

Received : 27 November 2017

Revised : 25 December 2017

Accepted : 03 January 2018

Online : 07 January 2018

Article Type

Original Article

\begin{abstract}
Öz: Bu araştırmanın genel amac1; Türkiye'de son beş yıl içinde (2013-2017), okul öncesi fen ve doğa eğitimi kapsamında yapılan çalışmaların incelenmesidir. Bu genel amaç doğrultusunda; fen ve doğa temelli araştırmalarda incelenen konuların, kullanılan araştırma yöntemlerinin ve (son olarak) araştırmalarda yer alan katılımeı grupların dağılımı incelenmiştir. Betimsel tarama modeli, çalışmanın yöntemi olarak tercih edilmiştir. Makale seçimlerinde; çalışmaların Türkiye'de son beş yıl içinde yapılmış olması, öncelikli tarama ölçütü olarak benimsenmiştir. Bunun yanı sıra, çalışmada yer verilen 40 araştırma; SSCI, ERIC, ULAKBIM ile bu endeksler dışında kalan ama alana özgü dergilerin (okul öncesi ve erken çocukluk eğitimi) tarandığı elektronik veri tabanları kullanılarak seçilmiştir. Elde edilen bulgulara göre, fen ve doğa temelli araştırmalarda; fen eğitimi ve uygulamalarına yönelik etkinlikler ile çevre eğitimi, yoğun olarak incelenen konular arasındadır. Nicel ve nitel paradigmalar, araştırma yöntemleri olarak dengeli dağılım gösterirken; karma araştırma yöntemlerin, çok az oranda tercih edildiği saptanmıştır. Son olarak, taranan çalışmalarda; çocukların, öğretmen ve öğretmen adaylarının örneklem grubu olarak dengeli şekilde dağı̆lım gösterdiği gözlenirken ebeveynlerle yürütülen çalışmaların sınırlı sayıda olduğu tespit edilmiştir.
\end{abstract}

Anahtar Kelimeler: Okul öncesinde fen ve doğa eğitimi, tarama çalışması, okul öncesi eğitimi

Abstract: The general purpose of this research is to examine the studies carried out during preschool science education in Turkey over the last five years (2013-2017). In accordance with this general purpose, the distribution of the topic studies, the research methods were used and finally the participant groups in the researches were examined. Descriptive screening model was used as research method. The primary criteria for selection of the articles are to examine the studies carried out in Turkey over the last five years. In addition to this, screening 40 studies included in the study were selected according to electronic databases in which SSCI, ERIC, ULAKBIM and other domainspecific journals (preschool and early childhood education journals). According to the findings, it is seen that, the activities towards science education and its applications, also the environmental educations are the most common examine topics in this study. While the quantitative and qualitative paradigms have balanced distribution as research methods, it has been found that mixed research methods are preferred in slightly. Finally, it has been found that although the distribution of studies carried out with children, teachers and pre-service teachers are common and balanced, there is limited number of studies carried out with parents.

Keywords: Preschool science education, screening study, preschool education 


\section{SUMMARY}

\section{Introduction}

The general purpose of this research is to examine the pre-school science education studies in Turkey over the last five years (2013-2017). The sub-problems of the research are as follows:

a. What is the distribution of the topics in preschool science education studies in Turkey during the past five years (2013-2017)?

b. What is the distribution of research designs, methods and techniques used in preschool science education studies in Turkey during the past five years (2013-2017)?

c. What is the distribution of participants (children, preservice teachers, teachers, parents, etc.) in preschool science education studies in Turkey during the past five years (2013-2017)?

The importance of the study is that by the help of the screening the pre-school science education studies in Turkey over the last five years, both to construct a profile of these studies according to topics, techniques and samples, as well as get the idea that the direction of the trends on preschool science education.

\section{Method}

Since the study based on the examination of science education studies in Turkey over the last five years, the descriptive screening model was chosen as a research method of study. Karasar (2006) describes the general screening models as; screening operations to reach some general judgments about a universe or a set of samples taken from the universe which compose of multitude of elements. Besides, in order to ensure the generalization of the results, by the help of the descriptive screening researches models are preferred as analyzing the relevant articles as much as possible so that the results can be obtained by systematic screening strategy, publication history, research method, results, and frequency analyzes (King and He, 2005).

\section{Screening criteria}

Screening 40 studies included in the study were selected according to electronic databases in which SSCI, ERIC, ULAKBIM and other domain-specific journals (preschool and early childhood education journals).

\section{Inclusion criteria}

The filter used for inclusion criteria include following keywords; science and science education in preschool, science and science education in early childhood education, science activities in preschool education, science activities in early childhood education, science in preschool education, science in early childhood education. 


\section{Results}

The research included 10 articles in 2017, eight articles in 2016 and 2015, and seven articles 2014 and 2013. It is seen that the distribution of the articles included in the study is balanced according to ratio of the years; articles in 2017 are 25\%, articles in 2016 and 2015 are 20\%, and articles in 2014 and 2013 are $17.50 \%$.

It can be said that preschool science researches are generally examined under the 10 headings. The total ratio of science education practices and activities, science and nature concepts, environmental education and also science concepts are approximately $74 \%$ among all study topics. It can be said that these four topics have been studied commonly in our national studies. Apart from these four topics, it seems that the ratio of studies on Science Process Skills and studies about scientists and their activities are nearly $15 \%$.

The ratio of experimental studies is calculated as $12.50 \%$. According to this, descriptive screening and experimental studies methods in used most of the studies in preschool science education (approximately $75 \%$ in totally). Techniques such as case study and content analysis ratios are $20 \%$.

It is observed that the proportion of studies in which carried out with children is higher than in the other participant groups in the study. The total proportion of the study carried out with teachers and preservice teachers was calculated as approximately $55 \%$. There is only one research that parents preferred as a sample.

\section{Conclusion and Discussion}

Research like unified field studies (science, math and technology) carried out in international preschool science education will improve our children's awareness of science and also indirectly contribute to the competitive power of our national science.

Mixed methods or alternative approaches in the paradigm choices of our national studies will allow us to obtain productive results and also enable to close position of international trends. It can be evaluated that intensively used interview questions in the researches are considered as an efficient data collection process, while the insufficient quantity choice of observation forms, picture drawings and caricatures can be considered as a problem for reaching the detailed information about data.

It is seen that, when the participant groups of the researches of the last five years (2013-2017) included in this study are examined, they are conducted with children, teachers and candidate teachers, which can be generally and equally balanced. Especially researches with children are expected to contribute to the evaluation and development of science education in the preschool and it will also have positive results in terms of determining the tendencies and attitudes of children to science and scientific thought. Although it is expected that the findings of the studies conducted with the pre-service teachers will reflect positive effects on the teacher training policies in the middle and long term, it is considered that 
carrying out the future researches in more proportions conducted with children, teachers and parents who are directly interacting with children will have more effective results in the short term.

\section{Implications}

Combined thematic screening studies covering science, mathematics and technology (unified field studies) can be conducted in preschool education. National and international studies on science can be examined through a cross-cultural comparative approach in preschool education. Science concepts and topics can be planned with alternative research designs in preschool education. Meta-analysis studies covering science topics can be conducted in preschool. More parent involvement studies related to science can be carried out in preschool education. 


\section{GİRIŞ}

Aristoteles'in, “İnsan doğası gereği bilmek ister." tespiti ile Sokrates'in "Sorgulanmamış bir hayat yaşamaya değmez." görüşü; bilmenin ve sorgulamanın medeniyet oluşumundaki önemine işaret etmektedir. İskenderiyeli ilk kadın filozof ve astronom Hypatia'nın, evreni ve evrenin yasalarını açıklama çabası da bilme ve sorgulama arzusunun yansımasıydı. Bilmenin ve sorgulamanın önemi her ne kadar milattan önce keşfedilse de, son yıllarda evrene ilişkin baş döndürücü sonuçlara ulaşılan CERN deneylerinin ve Mars araştırmalarının temelinde de insanoğlunun bilme ve sorgulama isteği yatmaktadır. Bilimsel ve teknolojik gelişmelerin felsefi temellerinin, bilmeye ve sorgulamaya dayalı olduğu görülmektedir. Bilme ve sorgulamanın en etkin uygulamalarını içeren fen ve doğa disiplinlerinin, parçası olduğumuz evreni anlama ve inşasından sorumlu olduğumuz geleceği kurma noktasında belirleyici bir etkiye sahip olduğu düşünülmektedir. $\mathrm{Bu}$ düşünceden hareketle, ülkeler, eğitim programlarında fen ve doğa konularına okul öncesi dönemde yer vererek; çocukların doğuştan getirdikleri meraklarının desteklenmesi ve oluşan keşfetme istekleri ile bilime karşı olumlu bir tutum sergilemelerini hedeflemektedir.

Çocukların doğuştan getirdikleri merakları bilme isteklerinin temelini oluştururken, keşfetme arzuları ise araştırma yeteneklerinin gelişiminde önemli bir rol oynar. Ünal ve Akman (2006), okul öncesi dönemde yapılan fen etkinliklerinin; çocukların meraklarını desteklemeye, doğal araştırma ve inceleme yapmalarına firsat vermeye, çocukların soru sormalarına ve çevrelerini tanımalarına imkân tanımaya yönelik olması gerektiğini belirtmektedir. Çevrelerini araştırmaktan ve keşfetmekten mutluluk duyan çocukların bu doğal eğilimlerinin bilim etkinliklerine uygulanması, ileride fen ve bilim konularına olan ilgilerini daha fazla artıracaktır (Eshach, 2006). Son dönemde yapılan çalışmalar, çocukların erken yaşlardan itibaren temel bilimsel kavramlara ilişkin anlayışlar geliştirebildiğine ve temel bilimsel süreç becerilerini (gözlem yapma, tanımlama, karşılaştırma yapma, sorgulama, tahminde bulunma, çıkarım yapma ve raporlama) kullanabildiğine işaret etmektedir (Kuhn ve Pearsall, 2000; Saçkes, Trundle ve Flevares, 2010).

Okul öncesi dönemde çocuklara sunulan nitelikli fen etkinlikleri; gözlemleme, sınıflama, iletişim kurma, ölçme, tahmin etme, sonuç çıkarma ve karşılaştırma yeteneklerini içeren bilimsel süreç becerilerinin geliştirilmesini sağlar. Fen eğitimi sayesinde, sadece bilimsel süreç becerilerinin gelişiminde değil; aynı zamanda çocukların içinde yaşadıkları dünyanın incelenmesi, araştırılması, öğrenilmeye değer olduğunun kavratılması ve bilime yönelik olumlu tutum geliştirilmesine katkı sağlanması da amaçlanır (Aktaş Arnas, 2002; Kuru ve Akman, 
2017; Murpy ve Smith, 2014). Bu bağlamda özellikle okul öncesi dönem çocuklarının fen ve doğa kavramlarına ilgilerinin artırılması, bilime karşı olumlu bir tutum kazandırılması ve doğal olarak yatkın oldukları bilimsel temelli düşünce sistemlerinin geliştirilmesi; tüm eğitim sistemlerinin öncelikleri arasındadır. Okul öncesinde yapılan fen ve doğa konulu araştırmaların; bu alanla ilgili eğitim sistemlerinin yeniden yapılandırılmasında, hedeflerin belirlenmesinde ve gerekli değişimlerin fark edilerek bu değişimlerin gerçekleştirilmesinde önemli bir etkiye sahip olduğu bilinmektedir. DeBoer (2000); doğal dünyayı anlayabilmemiz için ihtiyaç duyduğumuz bilim ile bilimin hedeflerini inceleyen araştırmaların, fen programlarının ve fen literatürünün değişimine ve gelişimine temel oluşturduğunu belirtmektedir.

\section{Araştırmanın Önemi}

Türkiye'de son beş yılda okul öncesi fen ve doğa eğitimi kapsamında yapılan çalışmaların incelenmesiyle elde edilen bulguların, ilerde bu alanda yapılacak çalışmaların yönüne ilişkin fikir vermesi araştırmanın başlıca önemi olarak görülmektedir. Bunun yanı sıra çalışmada yer verilen araştırmalarda incelenen içerik alanlarının, tercih edilen araştırma tekniklerinin ve örneklemlerin genel bir profiline ulaşılarak, okul öncesinde fen ve doğa konulu çalışmalara ilişkin alana katkı sağlayabilecek yeni çalışma konularının kestirilmesi, çalışmanın başka bir önemi olarak değerlendirilmektedir. Araştırmanın bir diğer önemi ise, ülkemizdeki bilime/fene karşı tutumun geliştirilmesi konusunda araştırmacıları teşvik etmek olarak görülebilir.

\section{Araştırmanın Amacı}

Araştırmanın genel amacı, Türkiye'de son beş yıl içinde (2013-2017), okul öncesi fen ve doğa eğitimi kapsamında yapılan çalışmaların incelenmesidir. $\mathrm{Bu}$ genel amaç doğrultusunda, araştırmanın alt problemleri, aşağıdaki gibi belirlenmiştir:

a. Türkiye'de son beş yıl içinde (2013-2017), okul öncesi fen ve doğa eğitimi kapsamında yapılan çalışmalarda, incelenen bilim/fen içerik alanlarının dağılımı nasıldır?

b. Türkiye'de son beş yıl içinde (2013-2017); okul öncesi fen ve doğa eğitimi kapsamında yapılan çalışmalarda tercih edilen araştırma desenleri, yöntem ve teknikleri ile kullanılan veri toplama araçlarının türlerinin dağılımı nasıldır?

c. Türkiye'de son beş yıl içinde (2013-2017), okul öncesi fen ve doğa eğitimi kapsamında yapılan çalışmalarda yer alan katılımcıların gruplara (çocuk, öğretmen adayları, öğretmenler, ebeveynler, vb.) göre dağılımları nasıldır? 


\section{Araştırmanın Sınırlılığı}

Araştırmanın son beş yılla sınırlı kalması, sadece elektronik veri tabanları üzerinden tarama yapılması ve belli sayıda makaleye yer verilmesi araştırmanın sınırlılığı olarak görülmektedir.

\section{YÖNTEM}

Araştırma, 2013-2017 yılları arasında ülkemizde yapılan okul öncesinde fen ve doğa konulu araştırmaların ulusal düzeyde incelenmesine dayalı olduğu için; betimsel tarama modeli, çalışmanın yöntemi olarak tercih edilmiştir. Karasar (2006), genel tarama modellerini; çok sayıda elemandan oluşan bir evrende, evren hakkındaki genel yargıya varmak amacı ile evrenin tümü ya da ondan alınacak bir grup örnek (ya da örneklem) üzerinde yapılan tarama düzenlemeleri olarak tanımlamaktadır. Bunun yanı sıra sonuçların genellenebilirliğini sağlamak için, araştırılan alanda mümkün olduğunca uygun makaleyi tarama ve analiz etme yöntemi olarak tercih edilen betimsel tarama yöntemiyle, sistematik bir tarama stratejisi, yayın tarihi, araştırma yöntemi, sonuçlar ve bu sonuçlara ilişkin frekans analizlerine ulaşılabilir ve böylece taranan araştırmalar betimsel açıdan incelenebilir (King ve He, 2005).

\section{Veri Toplama Süreci}

Araştırmada veri toplama süreci için iki ölçüt (tarama ve içerme) kullanılmıştır. İlk olarak tarama ölçütü için, makale seçimlerinde; çalışmaların Türkiye'de son beş yıl içinde yapılmış olması, öncelikli tarama ölçütü olarak benimsenmiştir. Bunun yanı sıra, çalışmada yer verilen 40 araştırma; SSCI, ERIC, ULAKBIM ile bu endeksler dışında kalan ama alana özgü dergilerin (okul öncesi ve erken çocukluk eğitimi dergileri) tarandığı elektronik veri tabanları kullanılarak seçilmiştir. İçerme ölçütü için ise, kullanılan filtrelemede; okul öncesinde fen ve doğa/fen eğitimi (science education in preschool), erken çocukluk eğitiminde fen ve doğa/fen eğitimi (science education in early childhood education), okul öncesinde fen ve doğa etkinlikleri (science activities in preschool education), erken çocukluk eğitiminde fen ve doğa etkinlikleri (science activities in early childhood education), okul öncesinde bilim (science in preschool education), erken çocukluk eğitiminde bilim (science in early childhood education) anahtar kelimeleri kullanılmıştır. 


\section{İçerme ölçütleri}

\section{Verilerin Çözümlenmesi}

Verilerin çözümlenmesinde içerik analizi kullanılmaktadır. İçerik analizinde elde edilen ham veriler (çalışmada yer verilen makaleler) kategorik olarak incelenmiş ve betimsel istatistikler için de frekans analizi kullanılmıştır.

İçerik analizinde, betimsel analizde özetlenen ve yorumlanan veriler konusunda daha derin analizlere ulaşılabilmesi ve betimsel yaklaşımda ihmal edilebilen kavramlar ve temaların keşfedilebilmesi, bu yöntemin veri analizinde kullanılmasının nedenini oluşturmaktadır (Selçuk, Palancı, Kandemir ve Dündar, 2014). İçerik analizi tekniğinin tercih edildiği çalışmalarda, verilerin kategorik halde incelenmesi, analiz sürecinin daha sistematik ve amaca yönelik olmasına katkı sağlamaktadır. Bu araştırmada verilerin kategorik hale getirilmesinde “disiplin”, “konu”, “yöntem-veri toplama araçları”, “örneklem ve veri analiz yöntemleri” olarak belirlenen kategoriler etkili olmuştur (Selçuk ve diğ., 2014).

Verilerin çözümlenme sürecinde Keleş ve Alisinanoğlu'nun (2014) araştırmalarında kullandığına benzer yapıda bir kodlama çerçevesi oluşturulmuştur. Oluşturulan kodlama çerçevesine ilişkin detaylı bilgiler Tablo 1'de sunulmuştur.

Tablo 1. 2013-2017 yılları arasında okul öncesi fen ve doğa eğitimi ile ilgili yapılan ulusal çalışmalardan seçilen 40 araştırmaya ilişskin kodlama çerçevesi

\begin{tabular}{|c|c|c|}
\hline Kategoriler & Kodlar & Açıklamalar \\
\hline \multicolumn{3}{|l|}{$\begin{array}{l}\text { Bilim/fen içerik } \\
\text { alanları }\end{array}$} \\
\hline & $\begin{array}{l}\text { Fen eğitimi etkinlik ve } \\
\text { uygulamaları (öğrenme ve bilgi } \\
\text { düzevleri) }\end{array}$ & $\begin{array}{l}\text { Fen eğitimi kapsamında uygulanan etkinliklere ve } \\
\text { etkinlikler sonucunda katılımcıların fene/bilime } \\
\text { iliskin bilgi düzevlerine vönelik arastırmalar }\end{array}$ \\
\hline & $\begin{array}{l}\text { Çevre eğitimi (etkinlikler, alg1 ve } \\
\text { tutum düzeyleri) }\end{array}$ & $\begin{array}{l}\text { Çevre eğitimi temalı çalışmalar, bu çalışmalar } \\
\text { sonucunda katılımcıların çevre konusundaki algıları } \\
\text { ve geliștirdikleri tutumlara ilişkin araştırmalar }\end{array}$ \\
\hline & $\begin{array}{l}\text { Fen kavramları (öğrenme ve bilgi } \\
\text { düzeyleri) }\end{array}$ & $\begin{array}{l}\text { Katılımcıların fen kavram (astronomi, biyoloji, } \\
\text { ekoloji, vb. gibi temel fen bilimleri konularına ilişkin } \\
\text { kavramsal bilgiler) düzeylerini belirlemeye yönelik } \\
\text { yürütülen araştırmalar }\end{array}$ \\
\hline & $\begin{array}{l}\text { Bilim kavramı (tanımı, bilimsel } \\
\text { düşünce ve bilimsel yöntem) }\end{array}$ & $\begin{array}{l}\text { Katılımcıların “fen/bilim”, "bilimsel düşünce ve } \\
\text { yöntem” hakkındaki tanımlamaları ile bu konulara } \\
\text { ilişkin görüşlerini inceleyen araştırmalar }\end{array}$ \\
\hline & Bilimsel Süreç Becerileri [BSB] & Katılımcıların "Bilimsel Süreç Becerileri” \\
\hline & $\begin{array}{l}\text { (tanımı, uygulamaları ve } \\
\text { kazanımı) }\end{array}$ & $\begin{array}{l}\text { hakkındaki görüşleri ve BSB kullanımını konu alan } \\
\text { araştırmalar }\end{array}$ \\
\hline & $\begin{array}{l}\text { Bilim insanı (alg1, tutum ve } \\
\text { çizimleri) }\end{array}$ & $\begin{array}{l}\text { Katılımcıların bilim insanı çizimlerini, tanımlarını ya } \\
\text { da bilim insanına ilişkin algılarını inceleyen } \\
\text { araştırmalar }\end{array}$ \\
\hline & $\begin{array}{l}\text { Ölçek geliştirme (BSB, Fen } \\
\text { eğitiminde problem çözme } \\
\text { becerileri) }\end{array}$ & $\begin{array}{l}\text { Okul öncesi eğitimde Fen/Bilim alanına yönelik } \\
\text { ölçek geliştirme araştırmaları }\end{array}$ \\
\hline
\end{tabular}


Fene karşı öncelik

Bilim merkezleri/ müzeler (alg1, tutum)

Bilimsel epistemolojik inançlar (tutum)
Katılımcıların uygulama (sınıf içi etkinlikler) ve ya teorik anlamda (disiplin alanları) fene/bilime verdikleri öncelikleri konu alan araştırmalar Geziler ve ya etkinlik ortamları için tercih edilen bilim merkezlerine/müzelere yönelik katılımcıların geliştirdikleri tutumları inceleyen çalışmalar ya da bu ziyaretlerden sonra fen/bilim algılarındaki değişimi konu alan araştırmalar

Katılımcıların okul öncesinde fen/bilim eğitimi kapsamında incelenen epistemolojik görüşleri konu alan araştırmalar

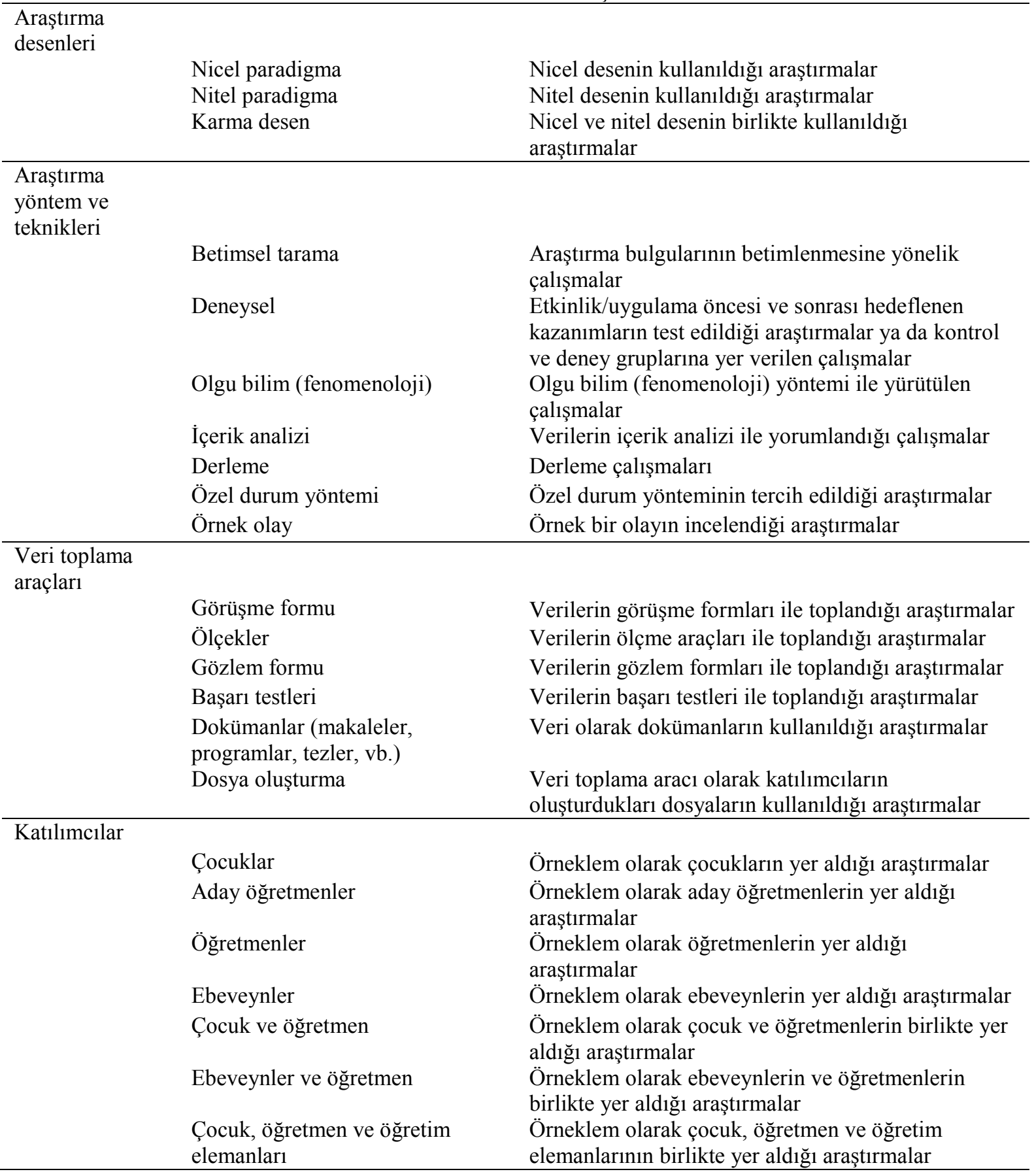

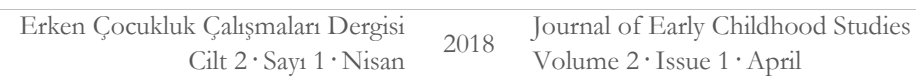




\section{BULGULAR}

2013-2017 yılları arasında okul öncesi fen ve doğa eğitimi ile ilgili yapılan ulusal çalışmalardan seçilen 40 araştırmanın, betimsel tarama sonuçlarına ilişkin bulgular

Son beş yıla ilişkin okul öncesinde fen ve doğa konulu ulusal yayınlardan seçilen çalışmaların betimsel istatistik sonuçları Tablo 2'de sunulmuştur.

Tablo 2. 2013-2017 yılları arasında okul öncesi fen ve doğa eğitimi ile ilgili yapılan ulusal çalışmalardan seçilen 40 araştırmanın betimsel tarama sonuçları

\begin{tabular}{|c|c|c|c|c|c|c|c|}
\hline \multicolumn{8}{|c|}{2017} \\
\hline & Yazar & Dergi & Endeks & $\begin{array}{l}\text { Araştırma } \\
\text { Modeli }\end{array}$ & $\begin{array}{l}\text { Araştırma Yöntem } \\
\text { ve Tekniği }\end{array}$ & Katılımcılar & Kullanılan Araç \\
\hline 1 & $\begin{array}{l}\text { Aydın ve } \\
\text { Güney }\end{array}$ & $\begin{array}{l}\text { Ahi Evran } \\
\text { Üniversitesi } \\
\text { Kırşehir Eğitim } \\
\text { Fakültesi Dergisi } \\
\text { (KEFAD) }\end{array}$ & ULAKBİM & Karma desen & Betimsel / Tarama & $\begin{array}{l}74 \text { okul öncesi } \\
\text { öğretmen aday1 }\end{array}$ & $\begin{array}{l}\text { Fen Kavramları Başarı Testi } \\
\text { (FKBT) ve yarı } \\
\text { yapılandırılmış görüşme } \\
\text { formları }\end{array}$ \\
\hline $\begin{array}{l}\text { Araştırmanın } \\
\text { Amacı/ Konusu } \\
\text { Araştırmanın } \\
\text { Sonucu }\end{array}$ & \multicolumn{7}{|c|}{$\begin{array}{l}\text { Çalışmada, yapılandırmacı yaklaşıma uygun olarak geliştirilen etkinliklerin okul öncesi öğretmen adaylarının fen kavramlarını öğrenmelerine } \\
\text { etkisinin incelenmesi amaçlanmıştır } \\
\text { Öğretmen adaylarının eksik bilgilerinin giderilmesine yönelik yapılan etkinliklerle, FKBT son-test lehine anlamlı bir farkın olduğu ve uygulanan } \\
\text { yarı yapılandırılmış görüşmeye ait verilerin de bu sonuçları destekler nitelikte olduğu görülmüştür. Yarı yapılandırılmış görüşme sonuçlarına } \\
\text { göre, yapılan etkinliklerin öğretmen adaylarının fen öğretimine yönelik ilgisizliklerini ve olumsuz düşüncelerini azalttığı ve giderdiği, fen kavram } \\
\text { bilgilerini arttırdığı sonuçlarına ulaşılmıştır. }\end{array}$} \\
\hline \multirow{6}{*}{$\begin{array}{l}\text { Araştırmanın } \\
\text { Amacı/ Konusu } \\
\text { Araştırmanın } \\
\text { Sonucu }\end{array}$} & Yazar & Dergi & Endeks & $\begin{array}{l}\text { Araştırma } \\
\text { Modeli }\end{array}$ & $\begin{array}{l}\text { Araştırma Yöntem } \\
\text { ve Tekniği }\end{array}$ & Katılımcilar & Kullanılan Araç \\
\hline & $\begin{array}{l}\text { Aydoğdu ve } \\
\text { Karakuş }\end{array}$ & $\begin{array}{l}\text { Kuramsal } \\
\text { Eğitimbilim } \\
\text { Dergisi }\end{array}$ & Diğer Endeksler & Nicel desen & Betimsel / Tarama & $\begin{array}{l}\text { Üç, dört ve beş } \\
\text { yaş grubundan } \\
228 \text { çocuk }\end{array}$ & $\begin{array}{l}\text { Okulöncesi Öğrencilerine } \\
\text { Yönelik Temel Beceri } \\
\text { Ölçeği }\end{array}$ \\
\hline & \multicolumn{7}{|c|}{ Çalışmanın amacı, "Okulöncesi Öğrencilerine Yönelik Temel Beceri Ölçeğii” geliştirmektir } \\
\hline & \multicolumn{7}{|c|}{$\begin{array}{l}20 \text { maddeden oluşan bilimsel süreç becerileri ölçeğinin güvenirlik katsayısı (KR-20) } 0.74 \text {, ölçeğin ortalama güçlüğü ise } 0.69 \text { olarak } \\
\text { belirlenmiştir. Alt ve üst \%27'lik grupların puanları arasındaki ayırt edicilikler incelendiğinde, ölçeğin bütün sorularının istatistiksel olarak } \\
\text { anlamlı biçimde ( }<<.01) \text { ayırt edici olduğu belirlenmiştir. Geliştirilen ölçeğin, okulöncesi öğrencilerinin temel becerilerini ölçmede uygun olduğu } \\
\text { düşünülmektedir. }\end{array}$} \\
\hline & \multirow[t]{2}{*}{ Yazar } & Dergi & Endeks & $\begin{array}{l}\text { Araştırma } \\
\text { Modeli }\end{array}$ & $\begin{array}{l}\text { Araştırma Yöntem } \\
\text { ve Tekniği }\end{array}$ & Katılımcılar & Kullanılan Araç \\
\hline & & & $\begin{array}{r}\text { en Çocukluk Çalışmaları } \\
\text { Cilt } 2 \cdot \text { Sayı } 1\end{array}$ & 2018 & $\begin{array}{l}\text { nal of Early Childhood Studie } \\
\text { ame } 2 \cdot \text { Issue } 1 \cdot \text { April }\end{array}$ & & \\
\hline
\end{tabular}



3 Güven ve
European Journal
of Sustainable
Diğer Endeksler
Nitel desen
Derleme
Çevre eğitimine ilişkin
Development

Araştırmanın $\quad$ Bu çalışmanın amacı, okul öncesi dönem çocuklarının çevre eğitimi üzerinde ailelerinin rolü ve öneminin tartışılmasıdır.

Araştırmanın Çevre bilincinin çocuklar daha okula başlamadan oluştuğu ve bu bilince yönelik eğitimin ailede başlaması gerektiği yorumlanmaktadır. Eğitim Sonucu programlarında çevre eğitimine yönelik uygulamaların olmasının çocuklarda gelişen çevre bilincine olumlu yönde katkı sağlayabilir.

Araştırma Araștırma Yöntem

\begin{tabular}{|c|c|c|c|c|c|}
\hline razal & Dergi & minuens & Modeli & ve Tekniği & Natmmenai \\
\hline $\begin{array}{l}\text { Harman ve } \\
\text { Çökelez }\end{array}$ & $\begin{array}{l}\text { Marmara } \\
\text { Üniversitesi } \\
\text { Atatürk Eğitim } \\
\text { Fakültesi Ĕ̆itim }\end{array}$ & ULAKBİM & Nitel desen & $\begin{array}{l}\text { Olgu bilim } \\
\text { (fenomenoloji) }\end{array}$ & $\begin{array}{l}70 \text { okul öncesi } \\
\text { öğretmen adayı }\end{array}$ \\
\hline
\end{tabular}

\section{Kullanilan Arac}

Fizik, kimya ve biyoloji kavramları için metafor cümleleri ile bu üç disiplin için zihinlerinde beliren üç kelime sorulmustur

Araştırmanın $\quad \mathrm{Bu}$ çalışma ile okul öncesi öğretmen adaylarının kimya, fizik ve biyoloji kavramlarına yönelik metaforik algılarının incelenmesi amaçlanmıştır. Amaci/ Konusu

Çalışma sonucunda olumlu metaforların sırası ile biyoloji, fizik ve kimya kavramlarına ilişkin olduğu belirlenmiştir. Okul öncesi öğretmen adaylarının biyolojiye yönelik algılarının fizik ve kimyaya yönelik algılarından daha olumlu olduğu görülmüştür. Kimya, biyoloji ve fizik için Araştırmanın olumlu metaforların yaşam ve doğa ile iç içe, nötr metaforların konu ve içerik, olumsuz metaforların ise zor ve karmaşık kategorilerinde Sonucu yoğunlaștı̆̆ saptanmıștır. Okul öncesi öğretmen adaylarının kimya, fizik ve biyoloji kavramları için zihinlerinde beliren ilk imgelerin kimya için periyodik cetvel ve element; fizik için basit makineler, kuvvet, hareket, hız, ivme, kütle, hacim, yoğunluk, yer çekimi; biyoloji için canlılar, bölünmeler, hücre, sistemler, fotosentez olduğu saptanmıştır.

\begin{tabular}{|c|c|c|c|c|c|c|c|}
\hline & Yazar & Dergi & Endeks & $\begin{array}{l}\text { Araştırma } \\
\text { Modeli }\end{array}$ & $\begin{array}{l}\text { Araştırma Yöntem } \\
\text { ve Tekniği }\end{array}$ & Katılımcılar & Kullanılan Araç \\
\hline 5 & $\begin{array}{l}\text { Kandemir, } \\
\text { Pekdoğan ve } \\
\text { Kandemir }\end{array}$ & $\begin{array}{l}\text { European Journal } \\
\text { of Education } \\
\text { Studies }\end{array}$ & Diğer Endeksler & Nicel desen & $\begin{array}{l}\text { Deneysel(ön-test ve } \\
\text { son-test) }\end{array}$ & $\begin{array}{l}40 \text { okul öncesi } \\
\text { öğretmen adayı }\end{array}$ & $\begin{array}{l}\text { Çevreye Karşı Motivasyon } \\
\text { Ölçeği kullanılmıştır }\end{array}$ \\
\hline
\end{tabular}

Araştırmanın Bu araştırmanın amacı, Etkinlik Tabanlı Çevre Eğitim Programının, okul öncesi öğretmen adaylarının çevre motivasyonları üzerine etkisini Amaci/ Konusu araştırmaktır.

Araştırmanın Araştırma sonunda, deney grubu ile kontrol grubu sonunda çevreye karşı motivasyon puanlarında istatistiksel olarak anlamlı farklar bulunmuştur.

Araştırmanın Etkinliğe dayalı çevre programlarının, deney grubunu oluşturan öğretmen adaylarının çevreye karşı olan motivasyonlarında olumlu bir rol oynadığ 1 tespit edilmiștir.

\begin{tabular}{|c|c|c|c|c|c|c|c|}
\hline & Yazar & Dergi & Endeks & $\begin{array}{l}\text { Araştırma } \\
\text { Modeli }\end{array}$ & $\begin{array}{l}\text { Araştırma Yöntem } \\
\text { ve Tekniği }\end{array}$ & Katılımcılar & Kullanılan Araç \\
\hline 6 & $\begin{array}{l}\text { Kuru ve } \\
\text { Akman }\end{array}$ & Eğitim ve Bilim & SSCI & Nicel desen & Betimsel / Tarama & $\begin{array}{l}250 \text { çocuk ve } 50 \\
\text { öğretmen }\end{array}$ & $\begin{array}{l}\text { Fen Süreçleri Gözlem } \\
\text { Formu ve Katılımcı Bilgi } \\
\text { Formları }\end{array}$ \\
\hline
\end{tabular}

$\begin{array}{ll}\text { Araştırmanın } & \text { Araştırma, ok } \\ \text { Amacı/ Konusu } & \text { yapılmıştır. }\end{array}$

$$
\begin{aligned}
& \text { Erken Çocukluk Çalışmaları Dergisi } 2018 \text { Journal of Early Childhood Studies } \\
& \text { Cilt 2·Say1 } 1 \cdot \text { Nisan } 2018 \text { Volume } 2 \cdot \text { Issue } 1 \cdot \text { April }
\end{aligned}
$$


Araștırmanın Çocukların yaş, devam ettikleri okul türü, okul öncesi eğitim alma durumu değişkenleri ile bilimsel süreç becerileri arasında anlamlı bir ilişki Sonucu $\quad$ olduğu sonucuna ulaşılırken, öğretmenlerin mesleki hizmet süresi ve yapmış oldukları fen etkinlik süreleri ile çocukların bilimsel süreç becerileri arasında anlamlı bir ilişki olmadığı görülmüștür.

\begin{tabular}{|c|c|c|c|c|c|c|c|}
\hline \multirow[b]{2}{*}{7} & Yazar & Dergi & Endeks & $\begin{array}{l}\text { Araştırma } \\
\text { Modeli }\end{array}$ & $\begin{array}{l}\text { Araştırma Yöntem } \\
\text { ve Tekniği }\end{array}$ & Katılımcılar & Kullanılan Araç \\
\hline & Ölçer & $\begin{array}{l}\text { International } \\
\text { Journal of } \\
\text { Environmental \& } \\
\text { Science } \\
\text { Education }\end{array}$ & ERIC & Nicel desen & Betimsel / Tarama & $\begin{array}{l}\text { Beş ve altı yaş } \\
\text { grubundan } 360 \\
\text { çocuk }\end{array}$ & $\begin{array}{l}\text { Erken Çocukluk Dönemi } \\
\text { Fen Eğitimi İçerik } \\
\text { Standartları Ölçeği (FİSÖ) }\end{array}$ \\
\hline $\begin{array}{l}\text { Araştırmanın } \\
\text { Amacı/Konusu }\end{array}$ & \multicolumn{7}{|c|}{ Çalışmanın amacı beş ve altı yaş grubu çocuklarının fen bilgisi içeriğine ilişkin görüşlerinin tespit edilmesidir } \\
\hline $\begin{array}{l}\text { Araştırmanın } \\
\text { Sonucu }\end{array}$ & \multicolumn{7}{|c|}{$\begin{array}{l}\text { FíSÖ toplam ve alt boyutların puanlarında, çocukların okul öncesi eğitime devam süreleri ve yaş değişkenleri arasında istatistiksel olarak anlamlı } \\
\text { fark bulunurken, çocukların cinsiyet ve ebeveynlerinin yaşlarının, FİSÖ toplam ve alt boyutların puanlarında herhangi bir farka neden olmadığı } \\
\text { tespit edilmiştir. Bunun yanı sıra, çocukların FISÖ puanlarında fizik alanından dünya ve uzay konularında, biyoloji konularına göre anlamlı } \\
\text { şekilde farklılaştıkları rapor edilmiştir. Bununla birlikte, ebeveynlerin eğitim durumlarının çocukların FISÖO puanlarında anlamlı şekilde farklılığa } \\
\text { neden olduğu görülmektedir. }\end{array}$} \\
\hline \multirow[b]{2}{*}{8} & Yazar & Dergi & Endeks & $\begin{array}{l}\text { Araştırma } \\
\text { Modeli }\end{array}$ & $\begin{array}{l}\text { Araştırma Yöntem } \\
\text { ve Tekniği }\end{array}$ & Katılımcılar & Kullanılan Araç \\
\hline & $\begin{array}{l}\text { Öztürk } \\
\text { Yilmaztekin } \\
\text { ve Erden }\end{array}$ & $\begin{array}{l}\text { Early Child } \\
\text { Development } \\
\text { and Care }\end{array}$ & ERIC & Nitel desen & Betimsel / Tarama & $\begin{array}{l}\text { Okul öncesi } \\
\text { öğretmenleri }\end{array}$ & $\begin{array}{l}\text { Görüşme soruları ve } \\
\text { öğretmenlerin sınıf içi } \\
\text { uygulamalarına ilişkin } \\
\text { gözlem formları }\end{array}$ \\
\hline $\begin{array}{l}\text { Araştırmanın } \\
\text { Amacı/ Konusu } \\
\text { Araştırmanın } \\
\text { Sonucu }\end{array}$ & \multicolumn{7}{|c|}{$\begin{array}{l}\text { Öğretmenler, fen etkinliklerinin çocukların öğrenme süreçlerinde önemli bir yere sahip olduğuna inandıklarını belirtmekte ve çocukları merkeze } \\
\text { alan yaklaşımlarla fen etkinliklerini planladıklarını belirtmişlerdir. Ayrıca öğretmenlerin doğal, enformel ve yapılandırılmış fen etkinliklerini } \\
\text { tercih ettikleri görülmektedir. Ayrıca araştırmaya katılan öğretmenlerin fen etkinliklerini değerlendirme aracı olarak kullandıkları tespit edilmiştir }\end{array}$} \\
\hline & Yazar & Dergi & Endeks & $\begin{array}{l}\text { Araştırma } \\
\text { Modeli }\end{array}$ & $\begin{array}{l}\text { Araştırma Yöntem } \\
\text { ve Tekniği }\end{array}$ & Katılımcılar & Kullanılan Araç \\
\hline 9 & Türkoğlu & $\begin{array}{l}\text { Kastamonu } \\
\text { Eğitim Dergisi }\end{array}$ & ULAKBİM & Nitel desen & Betimsel / Tarama & $\begin{array}{l}40 \text { okul öncesi } \\
\text { öğretmen adayı }\end{array}$ & Açık uçlu görüşme soruları, \\
\hline
\end{tabular}

Araştırmanın Çalışma, okul öncesi öğretmen adaylarının fen eğitimine ilişkin algılarını ve fen öğretimine ilişkin özgüvenlerini araştırmayı amaçlamaktadır.

Araştırmanın Tüm katılımcıların okul öncesi sınıflarında fen eğitiminin gerekliliğine inanmalarına rağmen, çoğunun kendisine güvenmediğini göstermiştir. 


\begin{tabular}{|c|c|c|c|c|c|c|c|}
\hline & Yazar & Dergi & Endeks & $\begin{array}{l}\text { Araştırma } \\
\text { Modeli }\end{array}$ & $\begin{array}{l}\text { Araştırma Yöntem } \\
\text { ve Tekniği }\end{array}$ & Katılımcılar & Kullanılan Araç \\
\hline 10 & $\begin{array}{l}\text { Yildirım ve } \\
\text { Özyılmaz } \\
\text { Akamca }\end{array}$ & $\begin{array}{l}\text { South African } \\
\text { Journal of } \\
\text { Education }\end{array}$ & Diğer Endeksler & Nicel desen & $\begin{array}{l}\text { Deneysel(ön-test ve } \\
\text { son-test) }\end{array}$ & $\begin{array}{l}\text { Düşük Sosyo- } \\
\text { ekonomik } \\
\text { düzeyli } \\
\text { ailelerden gelen } \\
\text { 58-66 aylık 35 } \\
\text { çocuk }\end{array}$ & Gözlem formu \\
\hline $\begin{array}{l}\text { Araştırmanın } \\
\text { Amaci/Konusu } \\
\text { Araştırmanın } \\
\text { Sonucu }\end{array}$ & \multicolumn{7}{|c|}{$\begin{array}{l}\text { Bu çalışmanın amacı, açık alan etkinliklerinin, okul öncesi dönem çocuklarının bilişsel, motor, dil ve sosyal-duygusal gelişimleri üzerine etkisinir } \\
\text { incelenmesidir. } \\
\text { Ön-test ve son-test sonuçlarına göre, açık alan etkinliklerinin, dezavantajlı okul öncesi dönem çocuklarının bilişsel, motor, dil ve sosyal-duygusal } \\
\text { gelişimleri üzerinde olumlu bir etkisinin olduğu ortaya çıkmıştır. }\end{array}$} \\
\hline \multicolumn{8}{|c|}{2016} \\
\hline & Yazar & Dergi & Endeks & $\begin{array}{l}\text { Araştırma } \\
\text { Modeli }\end{array}$ & $\begin{array}{l}\text { Araştırma Yöntem } \\
\text { ve Tekniği }\end{array}$ & Katılımcılar & Kullanılan Araç \\
\hline 11 & $\begin{array}{l}\text { Aksan ve } \\
\text { Çelikler }\end{array}$ & $\begin{array}{l}\text { Mustafa Kemal } \\
\text { Üniversitesi } \\
\text { Sosyal Bilimler } \\
\text { Enstitüsü Dergisi }\end{array}$ & ULAKBİM & Nitel desen & Betimsel / Tarama & $\begin{array}{l}35 \text { okul öncesi } \\
\text { öğretmen adayı }\end{array}$ & $\begin{array}{l}\text { Rastgele oluşturulmuş beşer } \\
\text { kişilik gruplardan fen } \\
\text { konularının öğretimine } \\
\text { yönelik drama etkinlikleri } \\
\text { planlamaları istenmistir }\end{array}$ \\
\hline $\begin{array}{l}\text { Araştırmanın } \\
\text { Amacı/ Konusu }\end{array}$ & \multicolumn{7}{|c|}{$\begin{array}{l}\text { Bu araştırma ile Okul Öncesi öğretmen adayları tarafından fen konularının öğretiminde dramanın kullanıldığı etkinlikler oluşturulması } \\
\text { amaçlanmıştır. } \\
\text { Araştırma sonucunda, öğretmen adaylarının hayvanlar ve özelliklerinin, ağız ve diş sağlı̆̆ının, el temizliğinin öneminin, kurbağanın başkalaşım } \\
\text { evrelerinin, dolaşım sisteminin, sindirimde görev alan organların öğretimine yönelik drama etkinlikleri ve etkinliklerde kullanılmak üzere } \\
\text { materyaller tasarladıkları belirlenmiştir. Araştırma sonucunda, öğretmen adaylarının hazırladıkları etkinliklerin, çocukların ilgisini çekecek, } \\
\text { eğlenceli, fen konularını öğrenmelerini kolaylaştırıcı, hazırladıkları materyallerin ise yeni fikirlerin oluşmasına olanak sağlayan ve hayal gücünü } \\
\text { geliştirici özellikte olduğu görülmüştür. }\end{array}$} \\
\hline \multirow{4}{*}{$\begin{array}{l}\text { Araştırmanın } \\
\text { Amacı/ Konusu } \\
\text { Araştırmanın } \\
\text { Sonucu }\end{array}$} & Yazar & Dergi & Endeks & $\begin{array}{l}\text { Araştırma } \\
\text { Modeli }\end{array}$ & $\begin{array}{l}\text { Araştırma Yöntem } \\
\text { ve Tekniği }\end{array}$ & Katılımcılar & Kullanılan Araç \\
\hline & $\begin{array}{l}\text { Duran ve } \\
\text { Ünal }\end{array}$ & $\begin{array}{l}\text { US-China } \\
\text { Education } \\
\text { Review A, }\end{array}$ & Diğer Endeksler & Nicel desen & $\begin{array}{l}\text { Deneysel (ön-test ve } \\
\text { son-test) }\end{array}$ & 10 çocuk & Gözlem formu \\
\hline & \multicolumn{7}{|c|}{ Bu çalışmanın amacı, test yönteminin okul öncesi dönemde çocukların bilimsel süreç becerileri üzerindeki etkilerini incelemektir } \\
\hline & \multicolumn{7}{|c|}{$\begin{array}{l}\text { Çocukların uygulanan test yöntemi ile fene karşı ilgilerini ve meraklarını artırdığı görülmüştür. Son-test sonuçlarına göre, uygulanan test } \\
\text { yönteminin çocukların bilimsel süreç becerilerini geliştirdikleri rapor edilmiştir. }\end{array}$} \\
\hline
\end{tabular}

$$
\begin{array}{rll}
\text { Erken Çocukluk Çalışmaları Dergisi } & 2018 & \begin{array}{l}
\text { Journal of Early Childhood Studies } \\
\text { Cilt } 2 \cdot \text { Sayı } 1 \cdot \text { Nisan }
\end{array} \\
\text { Volume } 2 \cdot \text { Issue } 1 \cdot \text { April }
\end{array}
$$




\begin{tabular}{|c|c|c|c|c|c|c|c|}
\hline \multirow[b]{3}{*}{$\begin{array}{l}\text { Araştırmanın } \\
\text { Amacı/ Konusu } \\
\text { Araştırmanın } \\
\text { Sonucu }\end{array}$} & Yazar & Dergi & Endeks & $\begin{array}{l}\text { Araştırma } \\
\text { Modeli }\end{array}$ & $\begin{array}{l}\text { Araştırma Yöntem } \\
\text { ve Tekniği }\end{array}$ & Katılımcılar & Kullanılan Araç \\
\hline & $\begin{array}{l}\text { Gençer ve } \\
\text { Akman }\end{array}$ & $\begin{array}{l}\text { İlköğretim } \\
\text { Online }\end{array}$ & ULAKBİM & Nicel desen & $\begin{array}{l}\text { Deneysel (ön-test ve } \\
\text { son-test) }\end{array}$ & $\begin{array}{l}\text { Altı yaş } \\
\text { grubundan } 98 \\
\text { çocuk }\end{array}$ & $\begin{array}{l}\text { Üç saatlik yaratıcı drama } \\
\text { eğitim programı öncesi ve } \\
\text { sonrası, çocukların 'Bilim } \\
\text { İnsanlarına' ilişkin } \\
\text { düşüncelerini tespite yönelik } \\
\text { soru formu uygulanmıştır. }\end{array}$ \\
\hline & \multicolumn{7}{|c|}{$\begin{array}{l}\text { Bu çalışmada, drama yöntemi kullanılarak çocukların drama çalışmaları öncesi ve sonrası bilim adamlarına ve icatlarına yönelik düşünceleri } \\
\text { arasında fark olup olmadığı incelenmiştir } \\
\text { Öntest-sontest uygulaması sonucu çocukların bilim insanları ve icatlarına yönelik cevaplarında, sontest lehine anlamlı farklılıklar görülmüştür. } \\
\text { Araştırma sonunda elde edilen bulgulara göre, yaratıcı drama yöntemi sayesinde katılımcıların bilim adamlarının kim olduğuna, neler } \\
\text { yaptıklarına, bilim adamlarının neleri icat ettikleri ile ilgili konularda fikir sahibi oldukları söylenebilir. }\end{array}$} \\
\hline & Yazar & Dergi & Endeks & $\begin{array}{l}\text { Araştırma } \\
\text { Modeli }\end{array}$ & $\begin{array}{l}\text { Araştırma Yöntem } \\
\text { ve Tekniği }\end{array}$ & Katılımcılar & Kullanılan Araç \\
\hline 14 & $\begin{array}{l}\text { İlhan ve } \\
\text { Tosun }\end{array}$ & $\begin{array}{l}\text { Cogent } \\
\text { Education }\end{array}$ & ERIC & Nicel desen & Betimsel / Tarama & $\begin{array}{l}335 \text { okul öncesi } \\
\text { grubu çocuk }\end{array}$ & $\begin{array}{l}\text { Anaokulu Öğrencilerinin } \\
\text { Bilimsel Kavramlar ve } \\
\text { Bilimsel Araştırma } \\
\text { Süreçlerine İlişkin Görüş } \\
\text { Ölçeği }\end{array}$ \\
\hline
\end{tabular}

Araştırmanın $\quad$ Bu çalışmanın amacı, anaokulu öğrencilerinin bazı bilim kavramlarını anlamadaki düzeylerini ve bilimsel araştırma süreçlerini belirlemek ve bazı Amacı/ Konusu demografik değişkenler açısından karşılaştırmaktır. Ayrıca, bu araştırmanın bir başka amacı da, demografik değişkenlerin çocukların bazı bilim

Araştırmanın Annenin eğitim düzeyi ve aile yapısı gibi değişkenlerin, çocukların bazı bilim kavramlarını anlamadaki düzeyleri ve bilimsel araştırma süreçleri Sonucu için istatistiksel olarak anlamlı bir fark yarattığı tespit edilmiştir. Bunun yanı sıra, yaş, ailenin gelir düzeyi ve kardeş sayısı gibi değișkenlerin çocukların bazı bilim kavramlarını anlamadaki düzeyleri ve bilimsel araştırma süreçleri için yordayıcı bir güce sahip olduğu rapor edilmiştir.

\begin{tabular}{|c|c|c|c|c|c|c|c|}
\hline & Yazar & Dergi & Endeks & $\begin{array}{l}\text { Araştırma } \\
\text { Modeli }\end{array}$ & $\begin{array}{l}\text { Araştırma Yöntem } \\
\text { ve Tekniği }\end{array}$ & Katılımcılar & Kullanılan Araç \\
\hline 15 & $\begin{array}{l}\text { Onur, } \\
\text { Çağlar ve } \\
\text { Salman }\end{array}$ & $\begin{array}{l}\text { Kastamonu } \\
\text { Eğitim Dergisi }\end{array}$ & ULAKBİM & Nitel desen & Betimsel / Tarama & $\begin{array}{l}\text { Beş grubu } \\
\text { çocuklar }\end{array}$ & $\begin{array}{l}\text { Görüşme, gözlem ve } \\
\text { resimleme yöntemi (Nitel) }\end{array}$ \\
\hline
\end{tabular}

Araştırmanın $\quad$ Bu çalışmada beş yaş grubu çocuklarında kâğıt israfının önüne geçebilmek ve çocuklarda atık kâğıt değerlendirme bilinci kazandırmak

Amaci/ Konusu amaçlanmıştır.

Araştırmanın Yapılan çalışmalarda erken yaşlarda verilen çevre eğitiminin etkisinin yaşam boyu devam ettiği görülmüştür. Araştırma sonunda çocuklarda Sonucu atıkların değerlendirilmesine karşı olumlu yönde değişimler gözlemlenmiştir

\begin{tabular}{llllll}
\hline Yazar & Dergi & Endeks & $\begin{array}{l}\text { Araştırma } \\
\text { Modeli }\end{array}$ & $\begin{array}{l}\text { Araştırma Yöntem } \\
\text { ve Tekniği }\end{array}$ & Katılımcılar \\
Kullanılan Araç
\end{tabular}

$$
\begin{array}{rll}
\text { Erken Çocukluk Çalışmaları Dergisi } & 2018 & \begin{array}{l}
\text { Journal of Early Childhood Studies } \\
\text { Collt } 2 \cdot \text { Sayı } 1 \cdot \text { Nisan }
\end{array} \\
\text { Volume } 2 \cdot \text { Issue } 1 \cdot \text { April }
\end{array}
$$


Özen Uyar

16 ve Yilmaz Genç
Journal of

Human Science
Diğer Endeksler

Karma desen

Olgu bilim

(fenomenoloji)
Altı yaş

grubundan 41

çocuk
Görüssme soruları ve The Children's Attitudes toward the Environment Scale-

Preschool Version (CATESPV) ölçeği

Araştırmanın Araştırmanın amacı, okul öncesi eğitime devam eden çocukların tüketim alışkanlıkları, çevreyi koruma, geri dönüşüm-yeniden kullanım ve

Amacı/ Konusu yaşam alışkanlıkları bakımından dört farklı çevresel konuya yönelik tutumlarının belirlenmesi ve yaşadıkları yerin çevreye yönelik tutuma yansımasının incelenmesidir

Araştırma sonucunda, çocukların tüketim alışkanlıkları, geri dönüşüm ve yaşam alışkanlıkları konularına ilişkin çevresel tutumlarının ilk bakışta

Araştırmanın ekosantrik olduğu ancak bu tutumlarının nedenleri incelendiğinde çoğunlukla antroposentrik tutuma sahip oldukları belirlenmiştir. Çocukların

Sonucu sadece çevreyi koruma alt boyutunda çoğunlukla ekosantrik tutuma sahip oldukları saptanmıştır. Ayrıca çocukların yaşadıkları yerin kentsel veya kırsal olmasının, çevreye yönelik tutumların farklılaşmasında önemli bir değişken olmadığı tespit edilmiştir.

\begin{tabular}{|c|c|c|c|c|c|c|c|}
\hline & Yazar & Dergi & Endeks & $\begin{array}{l}\text { Araştırma } \\
\text { Modeli }\end{array}$ & $\begin{array}{l}\text { Araştırma Yöntem } \\
\text { ve Tekniği }\end{array}$ & Katılımcılar & Kullanılan Araç \\
\hline 17 & $\begin{array}{l}\text { Uysal, } \\
\text { Tepetaş } \\
\text { Cengiz, } \\
\text { Güçhan } \\
\text { Özgül,Akar } \\
\text { Gençer ve } \\
\text { Akman }\end{array}$ & $\begin{array}{l}\text { Necatibey Eğitim } \\
\text { Fakültesi } \\
\text { Elektronik Fen } \\
\text { ve Matematik } \\
\text { Eğitimi Dergisi }\end{array}$ & ULAKBİM & Nitel desen & Betimsel / Tarama & $\begin{array}{l}58 \text { okul öncesi } \\
\text { öğretmeni }\end{array}$ & $\begin{array}{l}\text { Araştırmacılar tarafından } \\
\text { hazırlanmış olan “Okul } \\
\text { Öncesi Öğretmenlerinin } \\
\text { Bilim Defterleri ile ilgili } \\
\text { Görüşleri” isimli } \\
\text { yapılandırılmamış görüşme } \\
\text { formu kullanılmıştır }\end{array}$ \\
\hline
\end{tabular}

Araştırmanın $\quad$ Bu çalışmada öğretmenlerin bilim defterlerine ilişkin görüşlerini ortaya çıkararak bilim defterleri hakkında genel yaklaşımlarını belirlemek

Amaci/ Konusu amaçlanmaktadır

Araştırmanın Araştırma sonucunda bilim defterinin ne olduğu hususunda okul öncesi öğretmenlerinin \%29,3'ünün çocukların kullanırken meraklarını

Sonucu pekiştiren bir defter, \%20,7'si bilgi içerikli defter ve \%19'u ise bu konuda bir bilgisi olmadığını belirtmiştir.

\begin{tabular}{|c|c|c|c|c|c|c|c|}
\hline & Yazar & Dergi & Endeks & $\begin{array}{l}\text { Araştırma } \\
\text { Modeli }\end{array}$ & $\begin{array}{l}\text { Araştırma Yöntem } \\
\text { ve Tekniği }\end{array}$ & Katılımcılar & Kullanılan Araç \\
\hline 18 & $\begin{array}{l}\text { Yalçın, } \\
\text { Yalçın, } \\
\text { Bozan ve } \\
\text { Gecikli }\end{array}$ & $\begin{array}{l}\text { Bayburt Eğitim } \\
\text { Fakültesi Dergisi }\end{array}$ & Diğer Endeksler & Nitel desen & Betimsel / Tarama & $\begin{array}{l}72 \text { okul öncesi } \\
\text { öğretmeni }\end{array}$ & $\begin{array}{l}\text { Araştırmacılar tarafindan } \\
\text { hazırlanan beş maddeden } \\
\text { oluşan açık uçlu görüşme } \\
\text { soruları }\end{array}$ \\
\hline
\end{tabular}

Araștırmanın

Amaci/ Konusu

Sonucu

Bu çalışmanın amacı okul öncesi öğretmenlerinin çevre eğitimiyle ilgili görüşlerini belirlemektir.

sorular1 gerekliliğine vurgu yaptıkları ve okul öncesi eğitim programının çevre eğitimi açısından yetersizliğine dikkat çekmişlerdir. gerekliliğine vurgu yaptıkları ve okul öncesi eğitim programının çe

$\begin{array}{llllll}\text { Yazar } & \text { Dergi } & \text { Endeks } & \begin{array}{l}\text { Araştırma } \\ \text { Modeli }\end{array} & \begin{array}{l}\text { Araştırma Yöntem } \\ \text { ve Tekniği }\end{array} & \text { Katılımcılar }\end{array}$


Ceylan,

Sosyal Bilimler

Diğer Endeksler Nitel desen Betimsel / Tarama

35 anne ve 10

Araştırmacılar tarafından

19 Kahraman

Enstitüsü Dergisi

ve Ülker

ŏgretmeni

Açı uçlu

Bu çalışmanın amacı öğretmenlerin ve annelerin; çocukların bilim alanındaki bilgi ve meraklarını ne düzeyde bildiklerini ve merakların

$\begin{array}{ll}\text { Araştırmanın } & \text { Bu çalışmanın amacı öğretmenlerin ve annelerin; } \\ \text { Amacı/ Konusu } & \text { gidermede nasıl rehberlik ettiklerini araștırmaktır. }\end{array}$

Annelerin çocuklarının dünyayla ilgili merakları hakkında detaylı bir bilgiye sahip olmadıkları, öğretmenlerin ise çocukların daha çok dünyanın şekli ve boyutuna dair merakları olduğunu düşündükleri görülmüştür. Annelere göre çocukların gökyüzüyle ilgili meraklarına ay, yıldız ve bulut kavramları üzerine yoğunlaşmaktadır. Anneler de öğretmenler de, çocukların toprak altıyla ilgili en çok toprağın altında yaşayan canlıları merak

Araştırmanın ettiklerini düşünmektedirler. Öğretmenler çocukların; hayvanların yaşadıkları yerler, iletişim şekilleri, yaşam şekilleri, özellikleri ve ilk çağlarda

Sonucu yaşayan hayvanlar hakkında merakları olduğunu belirtmişlerdir. Anneler çocuklarının uzayla ilgili, en çok "Gezegen ve uzayın nasıl bir yer olduğunu" merak ettiklerini belirtmişlerdir. Öğretmenler ise yine bu görüşe paralel olarak, "Gezegenler ve uzayda yaşayan canlılar (Uzaylılar)" cevabını vermișlerdir. Anneler ve öğretmenlerin büyük çoğunluğu çocukların makinelerle ilgili "Nasıl çlıșı?” sorusunu sorduklarını belirtmişlerdir.

\begin{tabular}{|c|c|c|c|c|c|c|c|}
\hline & Yazar & Dergi & Endeks & $\begin{array}{l}\text { Araştırma } \\
\text { Modeli }\end{array}$ & $\begin{array}{l}\text { Araştırma Yöntem } \\
\text { ve Tekniği }\end{array}$ & Katılımcılar & Kullanılan Araç \\
\hline 20 & $\begin{array}{l}\text { Dilli ve } \\
\text { Bapoğlu } \\
\text { Dümenci }\end{array}$ & Eğitim ve Bilim & SSCI & Karma desen & Betimsel / Tarama & $\begin{array}{l}6 \text { yaş grubundan } \\
13 \text { çocuk }\end{array}$ & Müze eğitim programı \\
\hline
\end{tabular}

Araştırmanın Çalışmanın amacı okul öncesi dönemde çevre eğitiminin bir parçası olarak "nesli tükenmiş" kavramının nedenleriyle araştırılmasıdır.

Araştırmanın Araştırmada kullanılan anketler sonucunda deney grubunun Anadolu'da yaşamış nesli tükenmiş hayvanlarla ilgili bilişsel becerileri istatistiksel

Sonucu olarak anlamlı düzeyde yüksek bulunmuştur.

\section{Yazar \\ Dergi \\ Endeks}

\section{Eğitim ve}

21. Elmas ve Öğretim Kanmaz Araştırmaları Dergisi
Araştırma Araştırma Yöntem ve Tekniği

Model

Diğer Endeksler

Nicel desen

Betimsel / Tarama

184 okul öncesi

öğretmeni

\section{Kullanılan Arac}

Okul Öncesinde Fen Etkinliklerine İlişkin Öğretmen Yeterlik Ölçeği

Araştırmanın

Amaci/ Konusu

Araştırmanın

Bu araştırmada okul öncesi öğretmenlerinin fen etkinliklerine yönelik yeterliklerini tespit etmek amaçlanmıştır.

Sonucu etkinliklerine yönelik yeterlik puanları ile yas, kıdem ve mezun oldukları okul arasında anlamlı farklılık bulunmamıstır.

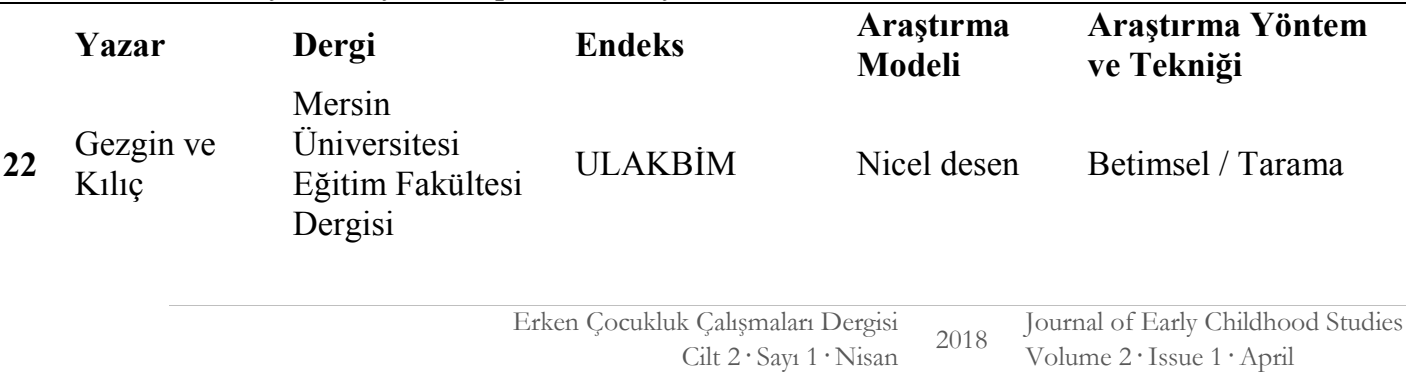

Katılımcılar

150 okul öncesi öğretmen

\section{Kullanılan Arac}

Fen Eğitimi Uygulamalar Değerlendirme Anketi ve görüşme soruları 
Araştırmanın Okul öncesi öğretmenlerinin fen eğitimi uygulamalarının değerlendirilmesi kapsamında fen etkinliklerini hangi kazanımlar için planladıkları ve Amaci/ Konusu kazanımlara ulaşmada tercih ettikleri yöntem ve tekniklerin belirlenmesi amaçlanmıştır.

Verilerin betimsel analizi sonucunda okul öncesi öğretmenlerinin, fen etkinliklerinin planlanması ve uygulanmasında en çok ve en az tercih

Araştırmanın ettikleri bilişsel alan kazanımları belirlenmiştir. Kullanılan yöntem ve teknikleri belirlemek için yapılan analiz sonucunda ise; her bir kazanım için Sonucu en fazla tercih edilen yöntem ve teknikler belirlenmiș, sonuç olarak eğitsel oyun, deney, drama, problem çözme ve kavram haritası yöntemlerinin en fazla tercih edilirken, analojinin en az tercih edildiği görülmüştür.

\begin{tabular}{|c|c|c|c|c|c|c|c|}
\hline & Yazar & Dergi & Endeks & $\begin{array}{l}\text { Araştırma } \\
\text { Modeli }\end{array}$ & $\begin{array}{l}\text { Araştırma Yöntem } \\
\text { ve Tekniği }\end{array}$ & Katılımcılar & Kullanılan Araç \\
\hline 23 & $\begin{array}{l}\text { Güngör } \\
\text { Seyhan }\end{array}$ & $\begin{array}{l}\text { Cumhuriyet } \\
\text { International } \\
\text { Journal of } \\
\text { Education-CIJE }\end{array}$ & Diğer Endeksler & Nitel desen & Betimsel / Tarama & $\begin{array}{l}210 \text { okul öncesi } \\
\text { ögretmen adayı }\end{array}$ & $\begin{array}{l}\text { Fen ve Doğa" konularına ait } \\
\text { "yaşam bilimleri, fiziksel } \\
\text { bilimler, dünya ve uzay } \\
\text { bilimleri ve ekoloji” alt } \\
\text { konuları için analoji } \\
\text { örnekleri }\end{array}$ \\
\hline
\end{tabular}

Araştırmanın Bu çalışmada, okulöncesi öğretmenlerinin fen ve doğa etkinliklerinde kullandıkları yöntem ve tekniklerden biri olan analojileri nasıl

Amacı/ Konusu kullanacakları hakkında bilgiler verilmesi ve okulöncesi dönemde "Fen ve Doğa" konularına ait ilgili analoji örneklerinin sunulması

Amaci/ Konusu amaçlanmıștır.

Araştırmanın Çalışmada bazı öğretmen adaylarının analojik ilişki kurma becerilerinin olmadığı da gözlenmiştir. Bu gruplarda araştırmacı yönlendirmesi çok Sonucu daha fazla olmuştur.

Sonucu

\section{Dergi}

Mustafa Kemal

Ogelman Üniversitesi

24 Gülay ve Sosyal Bilimler

Güngör $\quad$ Enstitüsü Dergisi

\section{Endeks}

ULAKBİM

\section{Araştırma Yöntem} ve Tekniği

Epistemolojik doküman analizi

\section{Katılımelar}

Nitel desen

Bu çalışmada, 2000-2014 yılları arasında Türkiye'de gerçekleştiril

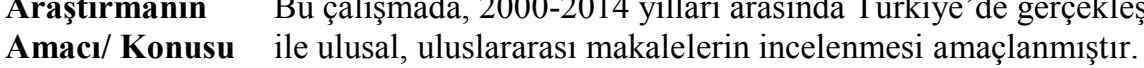

Araştırmanın

Sonucu Araştırmanın sonuçlarında ülkemizde konu ile ilgili tez ve makale çalışmalarının sayısının yeterli olmadığı görülmüştür.

\begin{tabular}{|c|c|c|c|c|c|c|c|}
\hline & Yazar & Dergi & Endeks & $\begin{array}{l}\text { Araştırma } \\
\text { Modeli }\end{array}$ & $\begin{array}{l}\text { Araştırma Yöntem } \\
\text { ve Tekniği }\end{array}$ & Katılımcılar & Kullanılan Araç \\
\hline
\end{tabular}

Araştırmanın

Amacı/ Konusu

Araștırmanın

Araştırmanın amacı okul öncesi öğretmenlerin fen etkinlikleri hakkındaki görüşlerinin belirlenmesidir Sonucu

Araştırma sonucunda okul öncesi öğretmenlerin fen etkinlikleri konusunda farkındalıklarının yüksek olduğu, lisans eğitimi dışında fen etkinlikleri ile ilgili bir eğitim almadıkları, fen etkinliklerini okul öncesinde gerekli gördükleri ve fen etkinliklerinin etkililiği konusunda olumlu bir görüşe

Beş yüksek lisans tezi, bir doktora tezi, üç ulusa makale ve yedi uluslararası makale

$$
\begin{aligned}
& \text { Erken Çocukluk Çalışsmaları Dergisi } 2018 \text { Journal of Early Childhood Studies } \\
& \text { Cilt } 2 \cdot \text { Say1 } 1 \cdot \text { Nisan } 2018 \quad \text { Volume } 2 \cdot \text { Issue } 1 \cdot \text { April }
\end{aligned}
$$


sahip oldukları belirlenmiştir. Öğretmenlerin fen etkinliklerini planlamada önceden hazırlanmış örneklerden yararlandıkları, her gün fen etkinliğine yer verdikleri, sınıflarında yeterliliği tartışılsa da bir fen öğrenme merkezi bulunduğu, fen etkinliklerinin amacı kazandırmada son derece etkili olduğunu düşündükleri ve fen etkinliklerinin kalıcı öğrenme sağlaması, dikkat ve algıyı arttırması, yaparak yaşayarak öğrenme fırsatı vererek çocukların yaşam deneyimlerini ve özgüvenlerini arttırması gibi olumlu etkileri olduğunu düşündükleri belirlenmiştir

\begin{tabular}{|c|c|c|c|c|c|c|c|}
\hline & Yazar & Dergi & Endeks & $\begin{array}{l}\text { Araştırma } \\
\text { Modeli }\end{array}$ & $\begin{array}{l}\text { Araştırma Yöntem } \\
\text { ve Tekniği }\end{array}$ & Katılımcılar & Kullanılan Araç \\
\hline 26 & $\begin{array}{l}\text { Ültay ve } \\
\text { Can }\end{array}$ & $\begin{array}{l}\text { Karadeniz Sosyal } \\
\text { Bilimler Dergisi }\end{array}$ & ULAKBİM & Nicel desen & Özel durum yöntemi & $\begin{array}{l}68 \text { okul öncesi } \\
\text { öğretmen adayı }\end{array}$ & $\begin{array}{l}\text { Araştırmacılar tarafından } \\
\text { hazırlanan } 14 \text { soruluk testler }\end{array}$ \\
\hline $\begin{array}{l}\text { Araştırmanın } \\
\text { Amacı/ Konusu }\end{array}$ & \multirow{2}{*}{\multicolumn{7}{|c|}{$\begin{array}{l}\text { Bu çalışmanın amacı okul öncesi öğretmen adaylarının ısı ve sıcaklık konusundaki kavramsal bilgilerinin ve konu ile ilgili sahip oldukları } \\
\text { alternatif kavramların belirlenmesidir. } \\
\text { Çalışmanın sonucunda öğretmen adaylarının ısı-sıcaklık konusundaki kavramsal bilgilerinin eksik olduğu bulunmuştur. Ayrıca öğretmen } \\
\text { adaylarının bu konuda oldukça fazla alternatif kavrama sahip oldukları görülmektedir. Örneğin "maddelerin sıcaklık tutma kapasitesi vardır", } \\
\text { "sıcaklık maddenin cinsine bağlıdı"”, "yünlü maddeler cisimleri sıcak tutmak için kullanılan en iyi maddedir" ve "maddeler arasındaki ısı } \\
\text { alışverişi madde miktarına bağlıdır" alternatif kavramları tespit edilen alternatif kavramlardan bazılarıdır. }\end{array}$}} \\
\hline $\begin{array}{l}\text { Araştırmanın } \\
\text { Sonucu }\end{array}$ & & & & & & & \\
\hline \multicolumn{8}{|c|}{2014} \\
\hline \multirow[b]{2}{*}{27} & Yazar & Dergi & Endeks & $\begin{array}{l}\text { Araştırma } \\
\text { Modeli }\end{array}$ & $\begin{array}{l}\text { Araştırma Yöntem } \\
\text { ve Tekniği }\end{array}$ & Katılımcılar & Kullanılan Araç \\
\hline & $\begin{array}{l}\text { Atasoy ve } \\
\text { Zorluoğlu }\end{array}$ & $\begin{array}{l}\text { Necatibey Eğitim } \\
\text { Fakültesi } \\
\text { Elektronik Fen } \\
\text { ve Matematik } \\
\text { Eğitimi Dergisi }\end{array}$ & ULAKBİM & Nitel desen & Betimsel / Tarama & $\begin{array}{l}25 \text { okul öncesi } \\
\text { öğretmeni, } 10 \\
\text { öğretim elemanı } \\
\text { ve } 76 \text { okul öncesi } \\
\text { çocuğu }\end{array}$ & $\begin{array}{l}\text { Çalışmada veri toplama } \\
\text { aracı olarak, araştırmacılar } \\
\text { tarafından tematik olarak } \\
\text { hazırlanan beş kavram } \\
\text { karikatürü kullanılmıştır }\end{array}$ \\
\hline $\begin{array}{l}\text { Araştırmanın } \\
\text { Amacı/ Konusu }\end{array}$ & \multirow{2}{*}{\multicolumn{7}{|c|}{$\begin{array}{l}\text { Bu çalışmanın amacı, okul öncesi dönemindeki çocuklara yönelik bazı fizik konularında kavram karikatürleri geliştirmek ve bunların } \\
\text { uygulanması sürecindeki yansımaları belirlemektir. } \\
\text { Geliştirilen materyallerin uygulanması sürecinde çocukların yönergeleri dikkatli bir şekilde dinledikleri, fikirlerini istekli bir şekilde söyledikleri } \\
\text { ve kullanılan görsellerden hoşlandıkları belirlenmiştir. Bu durum kavram karikatürlerinin onların kendilerini ifade edebilme becerilerini } \\
\text { desteklemesinden kaynaklanabilir. }\end{array}$}} \\
\hline $\begin{array}{l}\text { Araştırmanın } \\
\text { Sonucu }\end{array}$ & & & & & & & \\
\hline & Yazar & Dergi & Endeks & $\begin{array}{l}\text { Araştırma } \\
\text { Modeli }\end{array}$ & $\begin{array}{l}\text { Araştırma Yöntem } \\
\text { ve Tekniği }\end{array}$ & Katılımcılar & Kullanılan Araç \\
\hline 28 & $\begin{array}{l}\text { Karadeniz } \\
\text { ve Okvuran }\end{array}$ & $\begin{array}{l}\text { İlköğretim } \\
\text { Online }\end{array}$ & ULAKBİM & Nitel desen & İçerik analizi & $\begin{array}{l}17 \text { okul öncesi } \\
\text { öğretmen adayı }\end{array}$ & $\begin{array}{l}\text { Açık uçlu etkinlik soruları } \\
\text { ve ürün dosyaları }\end{array}$ \\
\hline $\begin{array}{l}\text { Araştırmanın } \\
\text { Amacı/ Konusu }\end{array}$ & \multicolumn{7}{|c|}{ Bu çalışma, okul öncesi öğretmen adaylarının müze eğitimine ilişkin etkinlik sürecini, öğrenci çalışmalarını ve öğrenci görüşlerini kapsamaktadır. } \\
\hline $\begin{array}{l}\text { Araştırmanın } \\
\text { Sonucu }\end{array}$ & \multicolumn{7}{|c|}{$\begin{array}{l}\text { Öğrencilerin tamamı, müzede uygulanan etkinliklerin büyük bölümünün okul öncesi çocuklarıyla rahatlıkla uygulanabileceğini düşünmektedir. } \\
\text { Çorum Arkeoloji Müzesi’nin atmosferinin buna olanak sağlayacağı da ayrıca vurgulanmıştır. Müzede Ara-Bul etkinliği öğrencilere göre eğlenceli } \\
\text { ve öğretici bir etkinliktir; çocukların merak ve dikkat düzeylerini artırmakta, müzenin tamamının keşfedilmesini ve kullanılmasını sağlamaktadır. }\end{array}$} \\
\hline & Yazar & Dergi & Endeks & $\begin{array}{l}\text { Araştırma } \\
\text { Modeli }\end{array}$ & $\begin{array}{l}\text { Araştırma Yöntem } \\
\text { ve Tekniği }\end{array}$ & Katılımcılar & Kullanılan Araç \\
\hline
\end{tabular}



Ogelman Uluslararas
29 Gülay ve
Sosyal
Durkan
Araștırmalar
Diğer Endeksler Nicel desen
Deneysel (ön-test ve
Beş-altı yaş
Dergisi
son-test)
grubundan 130
çocuk
Başarı testi

Araştırmanın Çalışmanın amacı, TÜBİTAK tarafından Doğa ve Bilim Okulları (4004) proje grubunda desteklenen Tipitop ve Arkadaşları ile Toprağı

Amaci/ Konusu Tanıyoruz 4 isimli projenin sonuçlarını sunmaktır

Araştırmanın Tipitop ve Arkadaşları ile Toprağı Tanıyoruz 4 isimli toprak eğitimi projesinin 2013 yılına ait sonuçları, 5-6 yaş çocuklarının toprakla ilgili

Araştırmanın
Sonucu konularda (hayvanlar, bitkiler, çevreyi koruma v.b.) bilgilerini pekiştirdikleri düșünülmektedir.

\begin{tabular}{|c|c|c|c|c|c|c|}
\hline Yazar & Dergi & Endeks & $\begin{array}{l}\text { Araştırma } \\
\text { Modeli }\end{array}$ & $\begin{array}{l}\text { Araştırma Yöntem } \\
\text { ve Tekniği }\end{array}$ & Katılımcılar & Kullanılan Araç \\
\hline $\begin{array}{l}\text { Olgan, } \\
\text { Alpaslan } \\
\text { Güner ve } \\
\text { Öztekin }\end{array}$ & Eğitim ve Bilim & SSCI & Nicel desen & Betimsel / Tarama & $\begin{array}{l}362 \text { okul öncesi } \\
\text { öğretmen adayı }\end{array}$ & $\begin{array}{l}\text { Epistemolojik İnanç Ölçeği } \\
\text { Fen Öğretimi Özyeterlik } \\
\text { İnanç Ölçeği ve Fen } \\
\text { Öğretimi Tutum Ölçeği }\end{array}$ \\
\hline
\end{tabular}

Araştırmanın Bu çalışmada, okul öncesi öğretmen adaylarının benimsedikleri bilimsel epistemolojik inançların, kişisel fen öğretimine yönelik özyeterlik

Amacı/ Konusu inançların ve tutumların onların fen öğretimine yönelik sonuç beklentisi inançlarına olan katkısı incelenmiştir.

Araştırmanın Analiz sonuçları, bilginin doğrulanması ve kişisel fen öğretimi özyeterlik inançlarının adayların fen öğretimine yönelik sonuç beklentisi

$\begin{array}{ll}\text { Sonucu } & \text { inançlarını açıklamada önemli rol oynadığını göstermiştir. Öte yandan, fen öğretimi } \\ \text { bilginin gelişen doğası hakkındaki görüşlerin ise katkı sağlamadığı belirlenmiştir. }\end{array}$

Yazar

\section{Dergi}

Early Childhood

31 Saçkes
Endeks

SSCI
Araştırma

Modeli

ve Tekniğ

Nicel desen

Quarterly

$\mathrm{Bu}$ araştırmanın amacı bilime/fene karşı ebeveynlerin öncelliklerinin incelenmesidir.

Araştırmanın

Amaci/ Konusu

Araștırmanın

Sonucu

Araştırma sonucuna göre, sekiz akademik alan içinde, çoğu ailenin anaokulunda fene/bilime karşı önceliğinin diğer konu alanları kadar olmadığı belirlenmiştir. Bunun yanı sıra yüksek SED' li, erkek çocuklu ve küçük çocuklu ebeveynlerin fene/bilime karșı önceliklerinin anlamlı șekilde örneklemden farklılaştığı rapor edilmiştir.

\begin{tabular}{|c|c|c|c|c|c|c|}
\hline \multirow{3}{*}{32} & Yazar & Dergi & Endeks & $\begin{array}{l}\text { Araştırma } \\
\text { Modeli }\end{array}$ & $\begin{array}{l}\text { Araştırma Yöntem } \\
\text { ve Tekniği }\end{array}$ & Katılımcılar \\
\hline & $\begin{array}{l}\text { Şenel ve } \\
\text { Aslan }\end{array}$ & $\begin{array}{l}\text { Mersin } \\
\text { Üniversitesi } \\
\text { Eğitim Fakültesi } \\
\text { Dergisi }\end{array}$ & ULAKBİM & Nitel desen & $\begin{array}{l}\text { Olgu bilim } \\
\text { (fenomenoloji) }\end{array}$ & $\begin{array}{l}96 \text { okul öncesi } \\
\text { öğretmen adayı }\end{array}$ \\
\hline & & & $\begin{array}{r}\text { Çocukluk Çalı } \\
\text { Cilt } 2\end{array}$ & $\begin{array}{l}\text { ergisi } \\
\text { Nisan }\end{array}$ & $\begin{array}{l}\text { nal of Early Childhood Studie } \\
\text { ame } 2 \cdot \text { Issue } 1 \cdot \text { April }\end{array}$ & \\
\hline
\end{tabular}


Araştırmanın Bu çalışma okul öncesi öğretmen adaylarının "Bilim” ve "Bilim İnsanı" kavramlarına yönelik sahip oldukları algıları metaforlar aracılığıyla Amacı/ Konusu ortaya çıkarmak amacıyla yapılmıştır.

Elde edilen bulgulara göre öğretmen adayları "Bilim” kavramı için 54, "Bilim İnsanı” kavramı için 49 geçerli metafor üretmiştir. Üretilen bu metaforlar daha sonra ortak özellikleri ve benzetme yönleri dikkate alınarak kategorileştirilmiştir. Bu işlem sonucunda "Bilim” kavramı için Araştırmanın dokuz, "Bilim İnsanı” kavramı için yedi kategori elde edilmiştir. Okul öncesi öğretmen adaylarının "Bilim” ve "Bilim İnsanı" kavramlarına Sonucu yönelik oluşturdukları metaforlar içinde olumsuz nitelikte bir metafora rastlanılmamıștır. Öğretmen adaylarının "Bilim" ve "Bilim İnsanı" algılarının olumlu yönde olduğu ancak her iki kavrama yönelik gerçekçi olmayan, geleneksel algılara sahip oldukları görülmüştür.

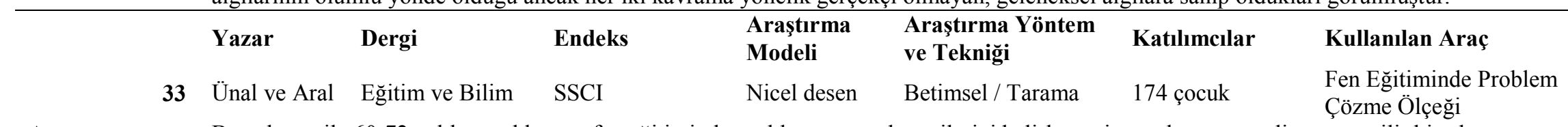

Araștırmanın Bu çalışma ile 60-72 aylık çocuklarının fen eğitiminde problem çözme becerilerini belirlemeyi amaçlayan geçerli ve güvenilir bir ölçme aracının Amacı/ Konusu geliştirilmesi amaçlanmıştır.

Elde edilen veriler üzerinden yapılan açımlayıcı faktör analizi sonucunda, ölçeğin 16 maddeden olușan iki faktörlü bir yapıya sahip olduğu belirlenmiştir. Ölçeğin Cronbach Alfa iç tutarlılık katsayısı 0,75 olarak hesaplanmıştır. Ölçeğin puanlanmasıyla ilgili güvenirliğin belirlenmesi

Araştırmanın için değerlendirmeciler arası tutarlılık hesaplanmış ve anlamlı bir farklılık görülmemiştir. Ölçeğin zamana karşı tutarlılığını belirlemek üzere dört Sonucu hafta arayla yapılan iki farklı uygulama arasındaki test- tekrar test korelasyon katsayısı ise 0,96 olarak hesaplanmıștır. Yapılan gecerlik ve güvenirlik analizleri sonucunda fen eğitiminde problem çözme becerileri ölçeğinin 6072 aylık çocuklar için geçerli ve güvenilir bir ölçek olduğu saptanmıştır.

\begin{tabular}{|c|c|c|c|c|c|c|c|}
\hline \multicolumn{8}{|c|}{2013} \\
\hline & Yazar & & Endeks & $\begin{array}{l}\text { Araştırma } \\
\text { Modeli }\end{array}$ & $\begin{array}{l}\text { Araştırma Yöntem } \\
\text { ve Tekniği }\end{array}$ & Katılımcılar & Kullanılan Araç \\
\hline 34 & $\begin{array}{l}\text { Altun ve } \\
\text { Demirtaş } \\
\text { Yıldız }\end{array}$ & $\begin{array}{l}\text { Mehmet Akif } \\
\text { Ersoy } \\
\text { Üniversitesi } \\
\text { Eğitim Fakültesi } \\
\text { Dergisi }\end{array}$ & ULAKBİM & Nitel desen & $\begin{array}{l}\text { Tek grup öntest - } \\
\text { sontest kontrol } \\
\text { grupsuz desen }\end{array}$ & 17 çocuk & $\begin{array}{l}\text { Okul Öncesi Bilim ve Bilim } \\
\text { insanı Algıları Görüşme } \\
\text { Formu }\end{array}$ \\
\hline
\end{tabular}

Araştırmanın Bu çalışmanın temel amacı, okulöncesi eğitime devam eden 6 yaş çocukları için hazırlanan Bilim ve Bilim İnsanı Öğretim Programı’nın,

Amacı/ Konusu çocukların bilim ve bilim insanı algıları üzerindeki etkisini ortaya çkarmaktır.

Araştırmanın Araştırma sonucunda “Bilim ve Bilim İnsanı Öğretim Programı’nın” çocukların bilim ve bilim insanına yönelik algılarını değiştirmede etkili Sonucu olduğu ortaya çıkmıştır.

\begin{tabular}{|c|c|c|c|c|c|c|c|c|}
\hline & & Yazar & Dergi & Endeks & $\begin{array}{l}\text { Araştırma } \\
\text { Modeli }\end{array}$ & $\begin{array}{l}\text { Araştırma Yöntem } \\
\text { ve Tekniŏi }\end{array}$ & Katılımcılar & Kullanılan Araç \\
\hline & 35 & Çınar & $\begin{array}{l}\text { Eğitim ve } \\
\text { Öğretim } \\
\text { Araştırmaları } \\
\text { Dergisi }\end{array}$ & Diğer Endeksler & Nitel desen & Örnek olay & $\begin{array}{l}15 \text { okul öncesi } \\
\text { öğretmeni }\end{array}$ & Gözlem ve görüşme soruları \\
\hline
\end{tabular}

Araştırmanın Okulöncesi öğretmenlerin fen ve doğa konuların öğretiminde kullandıkları öğretim etkinliklerini belirlemek ve bu etkinlikleri yürütürken Amacı/ Konusu karşılaştıkları problemleri tespit etmektir.

$$
\begin{aligned}
& \text { Erken Çocukluk Çalışmaları Dergisi _ } 2018 \text { Journal of Early Childhood Studie } \\
& \text { Cilt 2·Say1 1·Nisan } 2018 \quad \text { Volume 2·Issue 1·April }
\end{aligned}
$$


Okulöncesi öğretmenlerin büyük bir çoğunluğunun fen ve doğa konularının öğretiminde mutfak çalışmaları, doğa gezileri ve belgesel izleme

Araştırmanın etkinliklerini kullandığı, çok az bir kısmının koleksiyon ve araçları tanıma ve kullanma etkinliklerini yaptığı tespit edilmiştir. Etkinlikleri

Sonucu

yürütürken de öğretim kaynak materyalin ve araç-gereçlerin eksikliği, fen konu alan bilgilerinin yetersizliği ve velilerin ve idarenin olumsuz tutumu gibi sorunlarla karşılaştıkları ortaya çıkmıştır.

\begin{tabular}{|c|c|c|c|c|c|c|c|}
\hline \multirow[b]{3}{*}{$\begin{array}{l}\text { Araştırmanın } \\
\text { Amacı/ Konusu }\end{array}$} & Yazar & Dergi & Endeks & $\begin{array}{l}\text { Araştırma } \\
\text { Modeli }\end{array}$ & $\begin{array}{l}\text { Araştırma Yöntem } \\
\text { ve Tekniği }\end{array}$ & Katılımcılar & Kullanılan Araç \\
\hline & $\begin{array}{l}\text { Kefi, } \\
\text { Çeliköz ve } \\
\text { Erişen }\end{array}$ & $\begin{array}{l}\text { Ĕgitim ve } \\
\text { Öğretim } \\
\text { Araştırmaları } \\
\text { Dergisi }\end{array}$ & Diğer Endeksler & Nitel desen & $\begin{array}{l}\text { Betimsel / Betimsel / } \\
\text { Tarama }\end{array}$ & $\begin{array}{l}35 \text { okulöncesi } \\
\text { öğretmeni }\end{array}$ & $\begin{array}{l}\text { Öğretmen Bilgi Formu, } \\
\text { Öğretmen Mesleki Gelişim } \\
\text { Formu, Fen Etkinliği Örneği } \\
\text { Formu ve Öz değerlendirme } \\
\text { Formu }\end{array}$ \\
\hline & \multicolumn{7}{|c|}{$\begin{array}{l}\text { Bu çalışmanın amacı, okulöncesi eğitim kurumlarında görev yapan öğretmenlerin fen etkinlikleri sürecinde Temel Bilimsel Süreç Becerilerini } \\
\text { yeterli düzeyde kullanıp kullanmadıklarını belirlemektir }\end{array}$} \\
\hline $\begin{array}{l}\text { Araştırmanın } \\
\text { Sonucu }\end{array}$ & \multicolumn{7}{|c|}{ 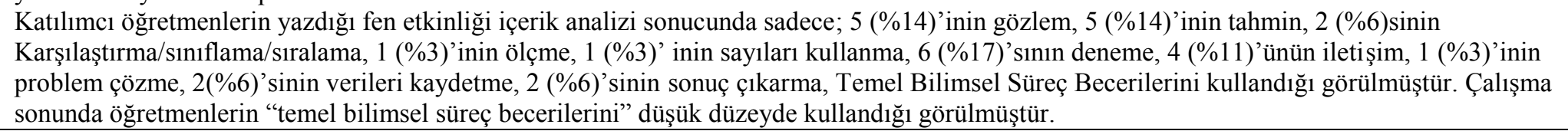 } \\
\hline \multirow[b]{2}{*}{37} & Yazar & Dergi & Endeks & $\begin{array}{l}\text { Araştırma } \\
\text { Modeli }\end{array}$ & $\begin{array}{l}\text { Araştırma Yöntem } \\
\text { ve Tekniği }\end{array}$ & Katılımcılar & Kullanılan Araç \\
\hline & $\begin{array}{l}\text { Özkubat ve } \\
\text { Demiriz }\end{array}$ & $\begin{array}{l}\text { Amasya } \\
\text { Üniversitesi } \\
\text { Eğitim Fakültesi } \\
\text { Dergisi }\end{array}$ & Diğer Endeksler & Nicel desen & Betimsel / Tarama & $\begin{array}{l}308 \text { okul öncesi } \\
\text { öğretmen aday1 }\end{array}$ & $\begin{array}{l}\text { Çevreye Karşı Motivasyon } \\
\text { Ölçeği }\end{array}$ \\
\hline Araştırmanın & \multirow{2}{*}{\multicolumn{7}{|c|}{$\begin{array}{l}\text { Bu araştırmanın amacı, Pelletier ve diğerleri (1998) tarafından geliştirilen Çevreye Karşı Motivasyon Ölçeğinin Okul Öncesi Öğretmen Adayları } \\
\text { Üzerinde Geçerlik Güvenirlik Çalışması'nın yapılmasıdır. } \\
\text { Yapılan geçerlik güvenirlik analizleri sonucunda } 6 \text { faktör ve } 24 \text { maddeden oluşan ölçeğin açıkladığı toplam Varyans Oranının \%74,61 ve } \\
\text { Cronbach } \alpha \text { iç tutarlılık kat sayısının .87 olduğu sonucu ortaya çıkmıştır. Araştırmaya katılan ögretmen adaylarının değişkenler açısından } \\
\text { değerlendirmesi yapıldığında; sınıf düzeylerine göre ölçeğin "İçe Yansıtılmış Düzenleme ve İçsel Düzenleme" boyutu puanları arasında anlamlı } \\
\text { fark yok iken diğer tüm alt boyutlarda farkların anlamlı olduğu ortaya çıkmıştır. Araştırmaya katılan öğretmen adaylarının annelerinin öğrenim } \\
\text { durumuna göre ölçeğin "İçsel Düzenleme" boyutunda farkın anlamlı olduğu sonucuna ulaşıllmıştır. Araştırmaya katılan öğretmen adaylarının } \\
\text { çevreye yönelik ders alma durumlarına göre ölçeğin "Bütünleşmiş Düzenleme " ve "İçe Yansıtılmış Düzenleme" boyutu puanlarıarasında anlamlı } \\
\text { fark olduğu sonucuna ulaşılmıştır. }\end{array}$}} \\
\hline $\begin{array}{l}\text { Araştırmanın } \\
\text { Sonucu }\end{array}$ & & & & & & & \\
\hline \multirow[b]{2}{*}{38} & Yazar & Dergi & Endeks & $\begin{array}{l}\text { Araştırma } \\
\text { Modeli }\end{array}$ & $\begin{array}{l}\text { Araştırma Yöntem } \\
\text { ve Tekniği }\end{array}$ & Katılımcılar & Kullanılan Araç \\
\hline & $\begin{array}{l}\text { Uğraş, } \\
\text { Uğraş ve Çil }\end{array}$ & $\begin{array}{l}\text { Bitlis Eren } \\
\text { Üniversitesi Fen } \\
\text { Bilimleri Dergisi }\end{array}$ & Diğer Endeksler & Nicel desen & Betimsel / Tarama & $\begin{array}{l}169 \text { okulöncesi } \\
\text { öğretmeni }\end{array}$ & $\begin{array}{l}\text { Fen Eğitimine Karşı Tutum" } \\
\text { ve "Fen Etkinliklerine } \\
\text { İlișkin Yeterlilik" }\end{array}$ \\
\hline
\end{tabular}

$\begin{array}{ll}\text { Araştırmanın } & \text { Araştırmanın am } \\ \text { Amacı/ Konusu } & \text { incelenmesidir. }\end{array}$

$$
\begin{array}{rll}
\text { Erken Çocukluk Çalışmaları Dergisi } & 2018 & \begin{array}{l}
\text { Journal of Early Childhood Studies } \\
\text { Collt } 2 \cdot \text { Sayı } 1 \cdot \text { Nisan }
\end{array} \\
\text { Volume } 2 \cdot \text { Issue } 1 \cdot \text { April }
\end{array}
$$


Araştırmanın Yapılan istatistiksel analizler sonucunda okulöncesi öğretmenlerinin fen eğitimine karşı tutumlarında ve fen etkinliklerine karşı yeterliliklerinde Sonucu mesleki deneyimleri ve görev yaptıkları bölgelere göre anlamlı bir farklılık olmadı̆̆

\begin{tabular}{|c|c|c|c|c|c|c|c|}
\hline & Yazar & Dergi & Endeks & $\begin{array}{l}\text { Araştırma } \\
\text { Modeli }\end{array}$ & $\begin{array}{l}\text { Araştırma Yöntem } \\
\text { ve Tekniği }\end{array}$ & Katılımcılar & Kullanılan Araç \\
\hline 39 & $\begin{array}{l}\text { Ünal ve } \\
\text { Akman }\end{array}$ & $\begin{array}{l}\text { Journal of } \\
\text { Academic Social } \\
\text { Sciences Studies }\end{array}$ & Diğer Endeksler & Nicel desen & Betimsel / Tarama & $\begin{array}{l}143 \text { okulöncesi } \\
\text { öğretmeni }\end{array}$ & $\begin{array}{l}\text { Okul Öncesi } \\
\text { Öğretmenlerinin Fen } \\
\text { Öğretimine Yönelik Tutum } \\
\text { Ölçeği }\end{array}$ \\
\hline Araştırmanın & \multicolumn{7}{|c|}{$\mathrm{Bu}$ araştırmanın amacı, okul öncesi öğretmenlerinin fen öğretimine yönelik tutumlarını belirlemektir. } \\
\hline $\begin{array}{l}\text { Araştırmanın } \\
\text { Sonucu }\end{array}$ & \multicolumn{7}{|c|}{$\begin{array}{l}\text { Öğretmenlerin eğitim düzeyi, hizmet süresi, hizmet içi eğitimlerinin, fen öğretim tutumlarında belirgin bir etkisi varken, çalıştıkları kurumların } \\
\text { etkisi olmadığı tespit edilmiştir. Lisans ve/ve ya yüksek lisans derecesine sahip öğretmenler, önlisans veya lise derecesine sahip öğretmenlere } \\
\text { kıyasla daha olumlu bir tutum benimsemektedir. } 1 \text { yıldan } 10 \text { yıla kadar çalışan öğretmenlerin, } 11 \text { ila } 15 \text { yıl ve } 16 \text { yıldan daha uzun süredir çalışan } \\
\text { öğretmenlere kıyasla fen öğretim tutumlarının daha olumlu olduğu rapor edilmiştir. }\end{array}$} \\
\hline & Yazar & Dergi & Endeks & $\begin{array}{l}\text { Araştırma } \\
\text { Modeli }\end{array}$ & $\begin{array}{l}\text { Araştırma Yöntem } \\
\text { ve Tekniği }\end{array}$ & Katılımcılar & Kullanılan Araç \\
\hline 40 & $\begin{array}{l}\text { Yurt ve } \\
\text { Ömeroğlu }\end{array}$ & $\begin{array}{l}\text { Bayburt } \\
\text { Üniversitesi } \\
\text { Eğitim Fakültesi }\end{array}$ & Diğer Endeksler & Nicel desen & $\begin{array}{l}\text { Ön ve son test } \\
\text { kontrol gruplu yarı } \\
\text { deneysel desen }\end{array}$ & 46 çocuk & $\begin{array}{l}\text {-Genel Bilgi Formu, } \\
\text {-Öğrenmeyi Değerlendirme } \\
\text { Testi }\end{array}$ \\
\hline $\begin{array}{l}\text { Araştırmanın } \\
\text { Amacı/ Konusu }\end{array}$ & \multirow{2}{*}{\multicolumn{7}{|c|}{$\begin{array}{l}\text { Bu araştırmada, okul öncesi eğitime devam eden } 60-72 \text { aylık çocukların bilim öğrenmelerinin desteklenmesinde Araştırmaya Dayalı Bilim Eğitim } \\
\text { Programı'nın etkisini belirlemek amaçlanmıştır. } \\
\text { Deney ve kontrol grubunda yer alan çocukların Bilim Öğrenmeyi Değerlendirme Testi toplamından ve alt testlerinden aldıkları puanlar arasında } \\
\text { deney grubu lehine anlamlı farklılık bulunmuştur }(p<.001) \text {. Eğitim programının kalıcılığına ilişkin yapılan kalıcılık testi sonucunda, eğitim } \\
\text { programının etkisinin devam ettiği saptanmıştır }(p>.05) \text {. }\end{array}$}} \\
\hline $\begin{array}{l}\text { Araştırmanın } \\
\text { Sonucu }\end{array}$ & & & & & & & \\
\hline
\end{tabular}

Tablo 2'de son beş yıla ilişkin ulusal düzeyde okul öncesi fen ve doğa konulu 40 çalışmaya yer verilmiştir. Çalışmaların yıllara göre dağılımı Grafik 1' de gösterilmiştir. 


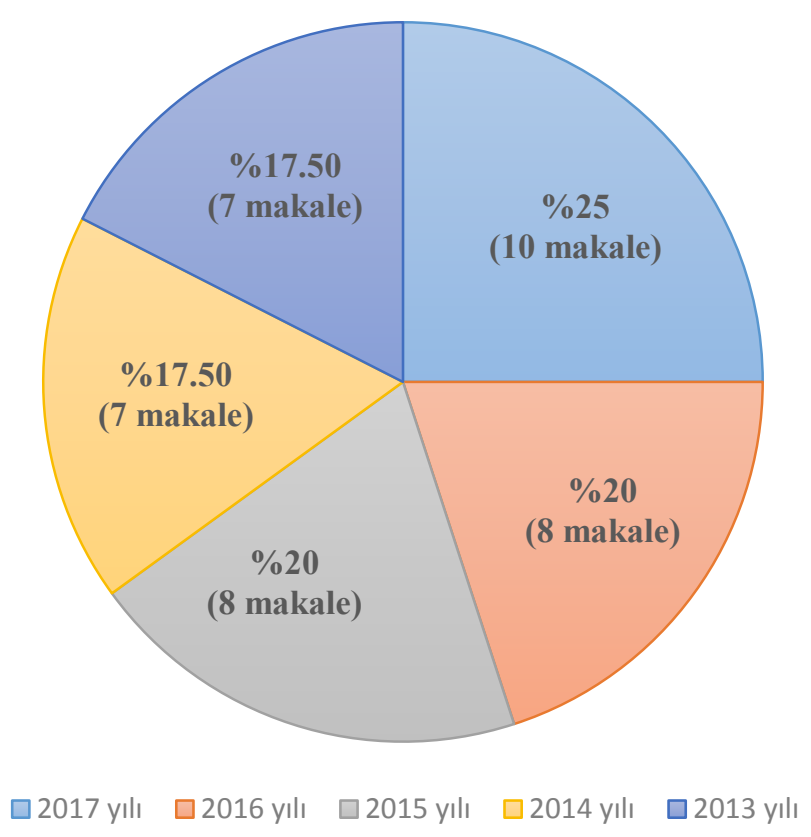

Grafik 1. Son Beş Yıla İlişkin Ulusal Fen ve Doğa Konulu 40 Makalenin Yıllara Göre Dağılımı

Araştırmanın veri toplama süreci sonunda ulaşılan makalelerin yıllara göre dağglımları Grafik '1 de sunulmuştur. Grafikteki dağılım incelendiğinde okul öncesinde fen ve doğa konulu makalelerin beş yıl içerisinde kısmen dengeli bir şekilde üretildiği, bunun yanı sıra son yıllarda bu makalelerde oransal bir artış olduğu görülmektedir

Çalışmada yer verilen makalelerin yayınlanan endeks bilgileri ile ilgili bilgiler, Tablo 3'de sunulmuştur.

Tablo 3. 2013-2017 yılları arasında, okul öncesi ĕgitimde, fen ve doğa alanında yayımlanan araştırmaların endeks bilgilerine ilişkin sonuçlar

\begin{tabular}{lll}
\hline Endeksler & f & $\mathbf{\%}$ \\
\hline Diğer Endeksler & 17 & 42.50 \\
ULAKBİM & 15 & 37.50 \\
SSCI & 5 & 12.50 \\
ERIC & 3 & 7.50 \\
Toplam & 40 & 100.00 \\
\hline
\end{tabular}

Tablo 3'de; okul öncesi fen ve doğa konulu çalışmaların \% 80'e yakının Diğer Endeksler (\% $42,50)$ ve ULAKBİM'de (\% 37,50) taranan dergilerde yayımlandığ 1 görülmektedir. SSCI ve ERIC tabanlı dergilerde ise toplam \% 20 oranında yayın dağılımı görülmektedir. Bu araştırmada yer verilen çalışmalardan elde edilen veriler, okul öncesinde fen ve doğa konulu araştırmaların sadece \% 20 oranında yüksek kalite içeren endekslere (ERIC ve SSCI) girebildiği ve ulusal bilimimiz için belirleyici bir kritere sahip ULAKBİM tabanında ise çalışmaların yer alma oranının \% 37,50’de kaldığg görülmektedir. 


\section{Son beş yıl içinde (2013-2017) okul öncesi eğitimde fen ve doğa alanında yapılan çalışmalarda incelenen konu dağılımlarına ilişsin bulgular}

Son beş yıl içinde (2013-2017) okul öncesi eğitimde fen ve doğa alanında yapılan çalışmalarda incelenen bilim/fen içerik alanlarının dağılımına ilișkin betimsel istatistik sonuçları, Tablo 4'de sunulmuştur.

Tablo 4. 2013-2017 yılları arasında okul öncesi eğitimde fen ve doğa alanında yapılan çalışmalarda incelenen bilim/fen içerik alanları dağılımlarına ilişkin betimsel istatistik sonuçları

\begin{tabular}{lll}
\hline Bilim/fen içerik alanları & f & $\mathbf{\%}$ \\
\hline Fen eğitimi etkinlik ve uygulamaları (öğrenme ve bilgi düzeyleri) & 11 & 26,19 \\
Çevre eğitimi (etkinlikler, alg1 ve tutum düzeyleri) & 9 & 21,43 \\
Fen kavramları (öğrenme ve bilgi düzeyleri) & 6 & 14,29 \\
Bilim kavramı (tanımı, bilimsel düşünce ve bilimsel yöntem) & 5 & 11,91 \\
Bilimsel Süreç Becerileri [BSB] (tanımı, uygulamaları ve kazanımı) & 3 & 7,14 \\
Bilim insanı (alg1, tutum ve çizimleri) & 3 & 7,14 \\
Ölçek geliştirme (BSB, Fen eğitiminde problem çözme becerileri) & 2 & 4,76 \\
Fene karşı öncelik & 1 & 2,38 \\
Bilim merkezleri/ müzeler (algı, tutum) & 1 & 2,38 \\
Bilimsel epistemolojik inançlar (tutum) & 1 & 2,38 \\
Toplam* & 42 & 100,00 \\
\hline
\end{tabular}

*Toplam: İki araştırmada, “bilim ve bilim insanı” temaları birlikte çalışıldığı için konu toplam sayısı 42 olarak hesaplanmıştır.

Tablo 4'de görüldüğü gibi okul öncesi fen ve doğa temalı araştırmaların genel olarak on başlık altında incelendiği söylenebilir. Bu başlıklardan fen eğitimi uygulama ve etkinlikleri, fen kavramları, çevre eğitimi ve bilim kavramı gibi konuların çalışılma oranının yaklaşık olarak tüm çalışma konuları arasında \% 74'e denk gelen bir orana sahip olduğu görülmektedir. Buradan hareketle ulusal çalışmalarımızda bu dört konu başlığının yoğun olarak çalışıldığı söylenebilir. Bu dört konunun dışında kalanların, BSB çalışmalarında ve bilim insanı konulu çalışmalarda \% 15'lik bir yüzdelik orana tekabül ettiği görülmektedir. Bu bakımdan, okul öncesi fen ve doğa konulu çalışmaların fen uygulama ve etkinlikleri; fen kavramları, bilim, bilim insanı, BSB ve çevre eğitimi alanlarında yürütüldüğü söylenebilir ( $\mathrm{Bu}$ altı konunun dağılım oranı, \% 90’a denk gelmektedir).

Son beş yıl içinde (2013-2017) okul öncesi eğitimde fen ve doğa alanında yapılan çalışmalarda kullanılan araştırma desenleri ile araştırma yöntem ve tekniklerine ilişkin bulgular

Çalışmada yer verilen makalelerde kullanılan araştırma desenlerine ilişkin bilgiler, Tablo 5'de sunulmuştur. 
Tablo 5. 2013-2017 okul öncesi eğitimde fen ve doğa alanında yapılan çalışmalarda kullanılan araştırma desenlerinin dă̆ılımı

\begin{tabular}{lll}
\hline Araştırma Desenleri & f & $\mathbf{\%}$ \\
\hline Nicel paradigma & 19 & 47,50 \\
Nitel paradigma & 18 & 45,00 \\
Karma paradigma & 3 & 7,50 \\
Toplam & 40 & 100,00 \\
\hline
\end{tabular}

Tablo 5'deki çalışmada yer verilen araştırmalarda tercih edilen desenlerin dağılımları incelendiğinde; okul öncesinde fen ve doğa konulu araştırmaların \% 47,50'sinde nicel paradigmanın, \% 7,50 gibi düşük bir oranda nicel ve nitel yaklaşımları aynı anda içeren karma yöntemin ve çalıșmaların \% 45'inde ise nitel paradigmanın tercih edildiği görülmektedir.

Çalışmada yer verilen makalelerde kullanılan araștırma yöntem ve tekniklerine ilişkin bilgiler, Tablo 6'da sunulmuştur.

Tablo 6. 2013-2017 yılları arasında okul öncesi eğitimde fen ve doğa alanında yapılan araştırmalarda kullanılan yöntem ve tekniklerin dağılımı

\begin{tabular}{lll}
\hline Çalışmalarda kullanılan araştırma yöntem ve teknikler & $\mathbf{f}$ & $\mathbf{\%}$ \\
\hline Betimsel tarama & 25 & 62,50 \\
Deneysel & 7 & 17,50 \\
Olgu bilim (fenomenoloji) & 3 & 7,50 \\
İçerik analizi & 2 & 5,00 \\
Derleme & 1 & 2,50 \\
Özel durum yöntemi & 1 & 2,50 \\
Örnek olay & 1 & 2,50 \\
Toplam & 40 & 100,00 \\
\hline
\end{tabular}

Tablo 6'da görüldüğü gibi, bu araştırmada yer verilen çalışmaların yarısından fazlasında betimsel tarama yöntemi kullanılmıştır. Deneysel çalışmaların oranı ise \% 17,50 olarak hesaplanmıştır. Buna göre okul öncesinde fen ve doğa konulu çalışmaların büyük bölümünü betimsel tarama ve deneysel çalışmalar (toplam \%80) oluşturmaktadır. Olgu bilim (fenomenoloji), veri analizi, derleme, özel durum yöntemi ve örnek olay tekniklerinin toplam tercih edilme oranlarının \% 20’de kaldığı görülmektedir.

Son beş yıl içinde (2013-2017) okul öncesi eğitimde fen ve doğa alanında yapılan çalışmalarda kullanılan veri toplama araçlarının türlerine ilişkin bulgular

Çalışmada yer verilen makalelerde kullanılan veri toplama araçlarının türlerine ilişkin sınıflamalar Frechtling'in (2002) önerilerine göre belirlenerek Tablo 7'de sunulmuştur. 
Tablo 7. 2013-2017 yılları arasında okul öncesi eğitimde fen ve doğa alanında yapılan araştırmalarda kullanılan veri toplama araçlarının dağılımı

\begin{tabular}{lll}
\hline Çalışmalarda kullanılan veri toplama araçlarının dağılımı & f & \% \\
\hline Görusme formu & 19 & 41,30 \\
Ölçekler & 13 & 28,30 \\
Gözlem formu & 6 & 13,00 \\
Başarı testleri & 4 & 8,70 \\
Dokümanlar (makaleler, programlar, tezler, vb.) & 3 & 6,50 \\
Dosya oluşturma & 1 & 2,20 \\
*Toplam & 46 & 100.00 \\
\hline
\end{tabular}

*Toplam: Bazı araștırmalarda birden fazla veri toplama aracı kullanıldığı için, veri toplama aracı toplam sayıSı 40'1 geçmektedir.

Tablo 7 incelendiğinde, çalışmada yer verilen makalelerin yaklaşık \% 90'1nda; görüşme formu, ölçekler, gözlem formu ve başarı testlerinin veri toplama yöntemi olarak tercih edildiği görülmektedir. Burada dikkat çekici nokta, incelenen çalışmalarda yoğunluklu olarak nitel temelli veri toplama aracı olan görüşme formlarının \%41.30, nicel temelli veri toplama aracı olan ölçeklerin ise \%28.30 oranında tercih edilmesidir. Ayrıca bu iki veri toplama aracı, çalışmada yer verilen diğer veri toplama araçları arasında, yaklaşık \% 70’lik bir kullanım oranına sahiptir.

Son beş yıl içinde (2013-2017) okul öncesi eğitimde fen ve doğa alanında yapılan çalışmalarda yer alan katılımcıların gruplara (çocuk, öğretmen adayları, öğretmenler, ebeveynler, vb.) göre dağılımlarına ilişkin bulgular

Çalışmada yer verilen makalelerin örneklem grubuna ilişkin bilgiler Tablo 8'de sunulmuştur.

Tablo 8. 2013-2017 yılları arasında okul öncesi eğitimde fen ve doğa alanında yapılan araştırmalarda yer alan katılımcı grupların dağılımı

\begin{tabular}{llc}
\hline Çalışmalarda yer alan katılımcı gruplar & $\mathbf{f}$ & $\mathbf{\%}$ \\
\hline Çocuklar & 13 & 34,20 \\
Aday öğretmenler & 11 & 28,90 \\
Öğretmenler & 10 & 26,30 \\
Ebeveynler & 1 & 2,60 \\
Çocuk ve öğretmen & 1 & 2,60 \\
Ebeveynler ve öğretmen & 1 & 2,60 \\
Çocuk, öğretmen ve öğretim elemanı & 1 & 2,60 \\
*Toplam & $\mathbf{3 8}$ & $\mathbf{1 0 0 , 0 0}$ \\
\hline
\end{tabular}

*Toplam: Üç araştırmada birden fazla katılımcı gruba yer verilirken iki araştırmada katılımcı grup yer almamaktadır, (doküman analizi çalışmaları) bu nedenle katılımcı grupların toplam sayısı 38'dir.

Tablo 8'de çocukların katılımcı olarak yer aldığı çalışmaların oranının çalışmada yer verilen diğer araştırmalardaki katılımcı grupların oranından daha fazla olduğu görülmektedir. 
Öğretmen ve öğretmen adayları ile gerçekleştirilen çalışmaların toplam oranı, yaklaşık olarak, \% 55 olarak hesaplanmıştır. Ebeveynlerin katılımcı olarak yer aldıkları sadece bir araştırmaya rastlanmıştır.

\section{SONUÇ VE TARTIŞMA}

Çalışmada yer alan makalelerin tarandığı endeksler dikkate alındığında, okul öncesinde fen ve doğa konulu araştırmaların \% 60'a yakın bir bölümünün; ULAKBİM, ERIC ve SSCI veri tabanlarında olduğu görülmektedir. Bu oranın da yaklaşık \% 65'inin ULAKBİM tabanlı yayınlar olduğu tespit edilmiştir. Bu bağlamda uluslararası anlamda yayın özelliği taşıyan araştırmaların çalışmada yer alan 40 makale içindeki oranı, \% 20 olarak hesaplanmıştır.

Çalışmada yer verilen araştırmaların incelediği konular, genel olarak, on başlık altında toplanabilir. Bu konu başlıkları içinde yer alan fen eğitimi etkinlik ve uygulamaları ile çevre eğitimi, araştırmada yer verilen çalışma konularının yaklaşık \% 48'ini oluşturmaktadır. Fen kavramları, bilim kavramı, BSB ve bilim insanı temalı çalışmaların tüm çalışma konularına oranı; \% 45 olarak hesaplanmıştır. Fen eğitiminde problem çözme, bilim merkezleri ve bilimsel epistemolojik inanç konulu araştırmalar ise konu dağılımı olarak \% 7'lik bir dilimi temsil etmektedir.

Araştırmadaki çalışmaların yarıya yakınında (\% 47,50) araştırma deseni olarak nicel paradigmanın temel alındığı; bu orana yakın bir oranda (\% 45), nitel paradigmanın tercih edildiği; çalışmalarda karma desenin model olarak kullanım oranının ise düşük olduğu saptanmıştır (\% 7,50). Tercih edilen paradigmalar bağlamında, betimsel tarama (\% 60) ve deneysel araştırma teknikleri (\% 15) olmak üzere yoğun şekilde (\% 75) uygulanmıştır. Fenomenoloji ve içerik analizlerinin kullanım oranları \% 12,50 olurken; derleme, özel durum, tek grup ön test-son test kontrol grupsuz desen, ön ve son test kontrol gruplu yarı deneysel desen ve örnek olay teknikleri de eşit şekilde geri kalan \% 12,50'lik oranı oluşturmaktadır. Veri toplama araçlarının incelenmesi sonucunda, görüşme formları ve ölçeklerin \% 60'lık oranda kullanıldığı; gözlem formu, başarı testleri, dokümanlar ve metafor çalışmaları için kullanılan cümle kalıplarının ise \% 35 oranında tercih edildiği hesaplanmıştır. Son olarak; veri toplama süreçlerinde resim çizimleri, dosya oluşturma ve karikatür kullanımları ise düşük bir oran sayılabilecek \% 5 seviyesinde tercih edilmiştir.

Çalışmanın son araştırma sorusu olan katılımcı grupların dağılımına ilişkin istatistik sonuçlarına göre çalışmaların \% 35'e yakınında doğrudan çocuklarla çalışılırken, \% 30'a yakınında aday öğretmenlerle ve \% 25 'ten biraz fazlasında ise öğretmenlerle çalışılmıştır. 
Doğrudan ebeveynlerle yürütülen sadece bir çalışmaya rastlanılırken araştırmaların biri anne ve öğretmenlerle; diğeri öğretmen ve çocuklarla; bir diğeri ise çocuk, öğretmen ve öğretim görevlileri ile gerçekleştirilmiştir.

Çalışmada yer alan makalelerin konuları incelendiğinde; (ulusal anlamda) astronomi, fizik, kimya ve biyoloji, ekoloji gibi daha tematik konuların çok fazla çalışılmadığı görülmektedir. Öte yandan, Vosniadou ve Brewer (1992), gözlemsel astronomi gibi uygulamalı çalışmaların; çocukların bilişsel gelişimine, bilimsel düşünme becerilerine etkide bulunduğunu ve olaylar arasında nedensellik ilişkisi kurabilmelerini desteklediğini belirtmektedir. Bunun yanı sıra Allen (2017), ekoloji çalışmalarının okul öncesi çocuklarda çok yönlü düşünme becerilerini hızla geliştirdiğine ve okul öncesi çocuklarının içinde yaşadığı ortamı anlamasını kolaylaştırdığına değinir. Biyoloji temalı başka bir araştırmada; beş yaş grubu çocuklarının biyolojiyi fen bilimleri olarak kabul ederken, fizik ve kimya alanındaki etkinlikleri doğa bilimleri olarak göremedikleri saptanmıştır. Biyoloji programı verilen bu grubun, fene karşı ilgilerinin ve doğa olayları ile ilgili yanıtlarının olumlu yönde geliştiği tespit edilmiştir. Bunun yanı sıra çocuklarda, kurs sonrası bilimle ilgili olarak "ne" ve "nasıl" sorularını tanımlamada ilerleme kaydettikleri gözlemlenmiştir (Thulin ve Redfor, 2017). Son zamanlarda, çocuklarla; spesifik fen temalarının yanı sıra STEM (Science, Technology, Engineering and Math) olarak adlandırılan "bilim, teknoloji, mühendislik ve matematik" alan ve disiplinlerini birleştiren bir yaklaşımla çeşitli uygulamalar yapılmaktadır. Stoll, Hamilton, Oxley, Eastman ve Brent (2012); küçük çocukların doğal kâşifler ve araştırmacılar olduğunu, her ne kadar bilimsel yöntem kavramını tanımlayamasalar da merakları ile problemleri bu yöntemi kullanarak çözmeye çalıştıklarını belirtmektedirler. Bu bağlamda STEM'in kalbi; sorular soran, çözecek problemleri bulan ve çevrelerindeki dünyayı eleştirel düşünme becerilerini içeren deneme yanılma yöntemini kullanarak çözen bir süreçtir (Wang ve diğerleri, 2013). Bu süreç, küçük çocuklar için bilimsel düşünme becerilerini geliştirme ve bilimsel yöntemi kullanmanın ilk basamağı olarak oldukça önemli bir rol oynar. Bu bağlamda STEM gibi birleştirilmiş konu alanları üzerinden yapılan etkinlik ve uygulamalar, çocukların bilişsel gelişimlerini de doğrudan etkileyerek fen bilimlerine olan ilgilerini olumlu açıdan geliştirecektir. Uluslararası okul öncesi fen ve doğa çalışmalarında yer verilen birleştirilmiş alan çalışmalarına ülkemizde de yer verilmesi, çocuklarımızın bilim konusundaki farkındalığını geliştirerek, dolaylı olarak, ulusal bilimimizin de rekabet gücüne büyük ölçüde olumlu katkı sağlayacaktır.

Bu bağlamda; son zamanlarda yapılan uluslararası bilimsel çalışmaların yöntemsel olarak nitel ve karma paradigmalara yöneldiği bir dönemde, ulusal anlamda yayınlanan bilimsel 
çalışmalarımızda, uluslararası yöntemsel paradigma eğiliminin dışında hareket ettiğimiz söylenebilir. Öte yandan her ne kadar paradigma açısından uluslararası eğilimden uzak bir görüntü sergilense de araştırmalarda seçilen veri toplama araçlarının nitel ve karma yöntemleri içermesi olumlu bir durum olarak değerlendirilebilir. Gage (1989) ve Hammersley (1992), geçtiğimiz yüzyılı paradigmaların savaşı olarak tanımlamakta ve özellikle eğitim bilimlerinde nicel ya da nitel yöntemlerin birbirine olan üstünlüğ̈̈nün tartışıldığııı belirtmektedirler. Symonds ve Gorard (2010), artık karma yöntemlerin de birçok sınırlılık taşıdığını ve eğitim bilimleri için yeni bir yöntem arayışının gerekliliğini vurgulamakta ve bu yeni yöntemin de yine karma desenlerin yeniden yorumlanması ile doğacağını belirtmektedir. Yeni doğacak paradigmaların; özellikle sosyal bilimler açısından son derece önem arz eden bilginin derinlemesine sunulması ve olaylara detaylı yanıt arama gayesinin yanı sıra, sonuçları nicel parametrelere dayandırarak güvenirlik ve geçerlik sorununu aşma yaklaşımlarını içereceği öngörülmektedir. $\mathrm{Bu}$ bağlamda; ulusal çalışmalarımızın paradigma seçimlerinde karma yöntemlere veya varyantları olabilecek yaklaşımlara daha fazla yer verilmesi, etkili sonuçlar alınmasına ve uluslararası eğilimlere yakın bir pozisyonda konumlanmamıza olanak sağlayacaktır.

Nicel paradigmaya uygun olarak kullanılan betimsel tarama ve deneysel yöntemlerin (ön testson test), okul öncesinde, fen ve doğa konulu çalışmaların temelini oluşturduğu görülmektedir. Buna karşın, son dönemde yapılan okul öncesinde fen ve doğa konulu araştırmalarda, nitel yaklaşımlar ve nitel veri toplama araçları yoğun şekilde kullanılmaktadır. Gomes ve Fleer (2017) dört yaş grubu çocuklarının günlük aktiviteleri ile fen becerileri ve fen kavramlarına ilişkin yaklaşımlarını; dört haftalık evde çekilen video kayıtları, ebeveynleri ile gerçekleştirdikleri görüşme ve gözlemler yoluyla açıklamaya çalışmışlardır. Video çekimleri, gözlem ve görüşme kayıtlarının derinlemesine analizleri sonucunda; çocukların fen kavram motiflerinin gündelik oyunlarında nasıl gerçekleştiği kayıt altına alınmıştır. Andersson ve Gullberg (2014); okul öncesi öğretmenlerinin fen etkinliklerini sınıf ortamında gerçekleştirirken ihtiyaç duydukları yeterlilikleri tespit etmek amacıyla gerçekleştirdikleri çalışmada, deneysel verilere dayalı nitel bir yaklaşım sergilemişlerdir. Yapılan araştırmada; öğretmenlere bir fen/doğa olayını (yüzme ve batma olayı) gösteren bir görsel sunularak, bu olayla ilgili epistemolojik bir tartışma yapılmıştır. Bu tartışmadan elde edilen bulgular incelendiğinde, öğretmenlerin kavram yanılgılarına sahip oldukları tespit edilmiştir. $\mathrm{Bu}$ bağlamda araştırmalarda kullanılan görüşme sorularının etkili bir veri toplama süreci olarak değerlendirilirken; gözlem formlarının, resim çizimlerinin, karikatürlerin yeterli miktarda 
tercih edilmemesi detaylı ve derinlemesine bilgiye ulaşma noktasında sorun olarak değerlendirilebilir.

$\mathrm{Bu}$ çalışmada yer verilen son beş yıla ait (2013-2017) araştırmaların katılımcı grupları incelendiğinde, genellikle ve dengeli sayılabilecek şekilde; çocuklar, öğretmenler ve aday öğretmenlerle yürütüldüğü görülmektedir. Özellikle çocuklarla yapılan araştırmaların okul öncesinde fen ve doğa eğitiminin değerlendirilmesine ve geliştirilmesine katkı sağlayacağı; bununla beraber çocukların fene, bilime ve bilimsel düşünceye olan eğilimlerinin ve tutumlarının belirlenmesi açısından da olumlu sonuçlar doğuracağı düşünülmektedir. Buna rağmen, taranan araştırmalarda, sadece ebeveynlerin örneklem olarak yer aldığı tek bir çalışma görülmektedir (Saçkes, 2014). Bununla birlikte, bu çalışmada yer verilen bir araştırmada da anne ve öğretmenler birlikte yer almaktadır (Ceylan, Kahraman ve Ülker, 2015). Bu bağlamda çocuklarla direkt teması olan ve öğrenme süreçlerinde önemli bir role sahip olan ebeveynlerin çalışmalarda yeterli düzeyde yer almaması, bir problem olarak değerlendirilebilir. Buradan hareketle ebeveynlerin okul öncesinde fen ve doğa çalışmalarında daha yoğun şekilde yer almaları; çocukların bilim, bilimsel düşünce ve fen kavramlarına ilişkin olumlu yaklaşımlar sergilemelerinde önemli bir etki yaratabilir. Bu noktada, Tuttle, Mentzer, Strickler, Bloomquist, Hapgood, Molitor, Kaderavek ve Czerniak (2017); aile çevresinde bilimsel öğrenmenin teşvik edilmesinin, okul dişında fen öğreniminin güçlenmesi için önemli bir fırsat olduğunu belirtmektedir. Ebeveynlerin fen ve doğa ile ilgili söylemleri ve çocukları ile paylaşımlarının, çocukların fene ilişkin çıkarımsal düşüncelerini geliştirdiğini belirtmektedirler. Bilimsel bakış açısını geliştiren merkezlerden olan hayvanat bahçesi ve kütüphane gezilerinde, ailelerin söylemlerinin ve çocuklarıyla olan etkileşimlerinin, çocukların fen ve fen kavramlarına ilişkin bilişsel gelişimlerine olumlu katkı sağladığını rapor edilmiştir (Tuttle ve diğerleri, 2017).

Brunsell ve Marcks (2005) öğretmenlerin bilimsel anlamalarının, öğrencilerin fen öğrenimi üzerinde çarpıcı etkileri olduğunu belirtmektedir. Bu bağlamda; çalışmada yer alan araştırmalardaki katılımcı grupların büyük bir bölümünü oluşturan öğretmen ve öğretmen adaylarının fen öğretimi, uygulama ve etkinlikleri ile fen kavramlarına ilişkin bilgi düzeylerinin incelenmesinin önemli olduğu düşünülmektedir. Buna rağmen, okul öncesinde fen ve doğa konulu her dört çalışmadan birinin sadece öğretmen adayları ile yürütülmesinin, çocukların fen bilgisi edinme düzeylerine ve bilimsel düşünmelerinin gelişimine doğrudan katkısının olmadığ1 ve çocukların fene ilişkin tutumları üzerinde güçlü bir yordayıcılık özelliği sunmadığı değerlendirilmektedir. Her ne kadar, aday öğretmenlerle yapılan çalışmalardan elde edilen bulguların öğretmen yetiştirme politikalarına yansımalarının, orta ve uzun vadede olumlu 
etkiler taşıyacağı beklense de gelecekteki araştırmaların, daha fazla oranlarda çocuklar, çocuklarla doğrudan etkileşim içinde olan öğretmenler ve ebeveynlerle yürütülmesinin kısa vadede daha etkili sonuçlar doğuracağı düşünülmektedir.

\section{ÖNERILER}

İleriye yönelik araştırmalarda okul öncesinde fen, matematik ve teknoloji konularını kapsayan birleşik temalı tarama çalışmaları yapılabilir. Okul öncesinde fen ve doğa konulu ulusal ve uluslararası çalışmalar, kültürler arası karşılaştırmalı bir yaklaşımla incelenebilir. Okul öncesinde, fen ve doğa konularına ilişkin alternatif araştırma desenlerinin kullanıldığı çalışmalar planlanabilir. Okul öncesinde, fen ve doğa konularını kapsayan meta analiz çalışmaları yapılabilir. Okul öncesinde, fen ve doğa konularını temel alan ve ebeveynlerin daha fazla çalışma grubu olarak yer aldığı araştırmalar yapılabilir.

Araştırmanın önemi ve bulgularından hareketle, okul öncesi uygulamacılarına yönelik fen etkinliklerini sınıf içi öğrenme ortamlarında daha fazla tercih etmeleri önerilmektedir. Okul öncesi öğretmenlerinin, fen eğitiminin doğası gereği hedeflenen kazanımların diğer etkinlik çeşitleri (drama, matematik, sanat, edebiyat, müzik ve oyun) ile birleştirmeleri fen başarısını olumlu yönde etkileyebilir. Bunun yanı sıra, öğretmenlerin fen temalı etkinliklerde aileleri öğrenme sürecine dahil eden bir yaklaşımı benimsemeleri hem ailelerin hem de çocukların fene/bilime karşı olan ilgilerini artıracak ve olumlu tutum geliştirilmesinde önemli bir rol oynayacaktır.

\section{KAYNAKÇA}

Aksan, Z., ve Çelikler, D. (2016). Dramatizasyon yöntemi ile okul öncesi çocuklara fen konularının öğretimine yönelik etkinlikler oluşturulması. Mustafa Kemal Üniversitesi Sosyal Bilimler Enstitüsü Dergisi, 13(35), 108-122.

Aktaş Arnas, Y. (2002). Okul öncesi dönemde fen eğitiminin amaçları. Çocuk Gelişimi ve Ĕ̈itimi Dergisi, 6(7), 1-6.

Allen, M. (2017). Early understandings of simple food chains: A learning progression for the preschool years, International Journal of Science Education, 39(11), 1485-1510.

Altun, E., ve Demirtaş Yıldız, V. (2013). 6 yaş çocukları için hazırlanan bilim ve bilim insanı öğretim programının etkililiği. Mehmet Akif Ersoy Üniversitesi Ĕ̈itim Fakültesi Dergisi, 13(27), 67-97.

Andersson, K. \& Gullberg, A. (2014). What is science in preschool and what do teachers have to know to empower children? Cultural Studies of Science Education, 9(2), 275-296.

Atasoy, Ş., ve Zoroğlu, M. a. (2014). Okul öncesi dönemdeki çocuklara yönelik kavram karikatürlerinin geliştirilmesi ve uygulanması. Necatibey Ĕgitim Fakültesi Elektronik Fen ve Matematik Ë̈itimi Dergisi, 8(2), 38-70. 
Aydın, A., ve Güney, M. Y. (2017). Yapılandırmacı yaklaşıma uygun olarak geliştirilen etkinliklerin okul öncesi öğretmen adaylarının fen kavramlarını öğrenmelerine etkisi. Ahi Evran Üniversitesi Kirşehir Eğitim Fakültesi Dergisi, 18, Özel Sayı, 181-201.

Aydoğdu, B., ve Karakuş, F. (2017). Okulöncesi öğrencilerinin temel becerileri: Bir ölçek geliştirme çalışması. Kuramsal Eğitimbilim Dergisi 10(1), 49-72.

Brunsell, E., \& Marcks, J. (2005). Identify a baseline for teachers' astronomy content knowledge. Astronomy Education Review, 3(2), 38-46.

Ceylan, Ş., Gözün Kahraman, Ö., ve Ülker, P. (2015).Çocukların meraklarına ilişkin annelerin ve öğretmenlerin düşünceleri: Bilim kavramı. Karabük Üniversitesi Sosyal Bilimler Enstitüsü Dergisi, 2015, 5(1), 1-16.

Çınar, S. (2013). Okul öncesi öğretmenlerin fen ve doğa konularının öğretiminde kullandıkları etkinliklerin belirlenmesi. Ĕ̌itim ve Öğretim Araştırmaları Dergisi, 2(1), 364-371.

DeBoer, G. E. (2000). Scientific literacy: Another look at its historical and contemporary meanings and its relationship to science education reform. Journal of Research In Science Teaching, 37(6), 582-601.

Dilli, R., ve Bapoğlu Dümenci, S. (2015). Okul öncesi dönemi çocuklarına Anadolu'da yaşamış nesli tükenmiş hayvanların öğretilmesinde müze eğitiminin etkisi. Eğitim ve Bilim, 40(181), 217-230.

Duran, M, \& Ünal, M. (2016). The impacts of the tests on the scientific process skills of the pre-school children. US-China Education Review A, 6(7), 403-411.

Elmas, H., ve Kanmaz, A. (2015). Okul öncesi eğitim öğretmenlerinin fen eğitimine ilişkin görüşlerinin belirlenmesi. Ë̆itim ve Öğretim Araştırmaları Dergisi, 4(2), 35-45.

Frechtling, J. (2002). The 2002 user friendly handbook for project evaluation. The National Science Foundation Directorate for Education \& Human Resources Division of Research, Evaluation, and Communication.

Gage, N.L. (1989). The paradigm wars and their aftermath: A "historical" sketch of research on teaching since 1989. Educational Researcher, 18(7), 4-10.

Gençer, A. A., ve Akman, B. (2016). Çocukların bilim insanları ve icatlarına yönelik fikirlerinin oluşumunda drama yönteminin etkisini incelemek. İlköğretim Online, 15(1), 161-171.

Gezgin, D., ve Kılıç, D. (2015). Okul öncesi öğretmenlerinin fen etkinliklerinde tercih ettikleri kazanım ve yöntemlerin belirlenmesi. Mersin Üniversitesi Ë̆itim Fakültesi Dergisi, $11(3), 620-630$.

Gomes, J., \& Fleer, M. (2017). The development of a scientific motive: How preschool science and home play reciprocally contribute to science learning. Research in Science Education, 1-22. DOI 10.1007/s11165-017-9631-5

Güngör Seyhan, H. (2015). Okul öncesi fen eğitiminde analoji kullanımının önemi ve analoji örnekleri. Cumhuriyet International Journal of Education-CIJE, 4(2), 15-28.

Güven, S., ve Yilmaz, N. (2017). Role and importance of family at preschool children environmental education. European Journal of Sustainable Development, 6(4), 105114.

Hammersley, M. (1992). What's wrong with ethnography? Methodological explorations. London: Routlege. 
Harman, G., ve Çökelez, A. (2017). Okul öncesi öğretmen adaylarının kimya, fizik ve biyoloji kavramlarına yönelik metaforik algıları.Marmara Üniversitesi Atatürk Eğitim Fakültesi Ĕ̈itim Bilimleri Dergisi, 46, 75-95.

İlhan, N., \& Tosun, C. (2016). Kindergarten students' levels of understanding some science concepts and scientific inquiry processes according to demographic variables (the sampling of Kilis Province in Turkey). Cogent Education, 3(1), 1144246.

Kandemir, N., Pekdemir, S., \& Kandemir, Ş. (2017). Examination of the effect of the environment education application on the environmental attitudes of prospective preservice pre-school teachers. European Journal of Education Studies, 3(6), 728-741.

Karadeniz, C., ve Okyay, A. (2014). A Night at the Museum: Museum Education with Ankara University Students at Çorum Museum of Archeology. Elementary Education Online Journal, 13(3), 865-879.

Karasar, N.(2006). Bilimsel araştırma yöntemi. Ankara: Nobel Yayın Dağıtım.

Kefi, S., Çeliköz, N., ve Erişen, Y. (2013). Okulöncesi eğitim öğretmenlerinin temel bilimsel süreç becerilerini kullanım düzeyleri. Ĕgitim ve Ö̆rretim Araştırmaları Dergisi, 2(2), 300-319.

Keleş, S., ve Alisinanoğlu, F. (2014). Okul öncesi öğretmenlerinin vygotsky'nin kendine yönelik konuşma terimine ilişkin gözlemleri ve görüşleri. İlkögretim Online, 13(1), 205222.

King, W. R. \& He, J. (2005). Understanding the role and methods of meta-analysis in IS research. Communications of the Association for Information Systems, 16, 665-686.

Kuhn, D., \& Pearsall, S. (2000). Developmental origins of scientific thinking. Journal of Cognition and Development, 1, 113-129.

Kuru, N., ve Akman, B. (2017). Okul öncesi dönem çocuklarının bilimsel süreç becerilerinin öğretmen ve çocuk değişkenleri açısından incelenmesi. Ĕgitim ve Bilim, 42(190), 269279.

Murpy, C. ve Smith, G. (2014). The impact of a curriculum course on pre-service primary teachers' science content knowledge and attitudes towards teaching science. Irish Educational Studies, 31(1), 77-95.

Ogelman Gülay, H., ve Durkan, N. (2014). Toprakla buluşan çocuklar: küçük çocuklar için toprak eğitimi projesinin etkililiği. Uluslararası Sosyal Araştırmalar Dergisi, 7(31), 632-638.

Ogelman Gülay, H., ve Güngör, H. (2015). Türkiye'deki okul öncesi dönem çevre eğitimi çalışmalarının incelenmesi: 2000-2014 yılları arasındaki tezlerin ve makalelerin incelenmesi. Mustafa Kemal Üniversitesi Sosyal Bilimler Enstitüsü Dergisi, 12(32), 180-194.

Olgan, R., Alpaslan Güner, Z., ve Öztekin, C. (2014). Okul öncesi öğretmen adaylarının fen öğretimine yönelik sonuç beklentisi inançlarını etkileyen faktörler. Ĕgitim ve Bilim, 39(173), 288-300.

Onur, A., Çağlar, A., Salman, M. (2016). 5 yaş okulöncesi çocuklarda atık kâğıtların değerlendirilmesi ve çevre bilincinin kazandırılması.Kastamonu Ĕ̆itim Dergisi, 24(5), 2457-2468.

Ölçer, S. (2017). Science content knowledge of 5-6 year old preschool children. International Journal of Environmental \& Science Education, 12(2), 143-175. 
Özen Uyar, R., \& Y1lmaz Genç, M. M. (2016). Okul öncesi dönem çocukların farklı çevre konularına yönelik ekosantrik ve antroposentrik tutumları. Journal of Human Sciences, 13(3), 4579-4594.

Özkubat, S., ve Demiriz, S. (2013). Çevreye karşı motivasyon ölçeğinin okul öncesi öğretmen adayları üzerinde geçerlik güvenirlik çalışması.Amasya Üniversitesi Eğitim Fakültesi Dergisi, 2(1), 87-114.

Öztürk Yilmaztekin, E., \&Erden, F. T. (2017). Investigating early childhood teachers' views on science teaching practices: The integration of science with visual art in early childhood settings. Early Child Development and Care, 187(7), 1194-1207.

Saçkes, M. (2014). Parents who want their PreK children to have science learning experiences are outliers. Early Childhood Research Quarterly, 29(2), 132-143.

Saçkes, M. Flevares, L. M., Gonya, M., \& Trundle, K. C. (2012). Preservice early childhood teachers' sense of efficacy for integrating mathematics and science: Impact of a methods course. Journal of Early Childhood Teacher Education, 33(4), 349-364.

Sağlam, M. ve Aral, N. (2015). Okul öncesi öğretmenlerin fen etkinlikleri hakkındaki görüşlerinin belirlenmesi. İn̈nü Üniversitesi Eğitim Fakültesi Dergisi, 16(3), 87-102.

Selçuk, Z., Palancı, M., Kandemir, M., \& Dündar, H. (2014). Eğitim ve bilim dergisinde yayınlanan araştırmaların eğilimleri: İçerik analizi. Eğitim ve Bilim, 39(173), 430-453.

Stoll, J., Hamilton, A., Oxley, E., Eastman, A. M., \& Brent, R. (2012). Young thinkers in motion: Problem solving and physics in preschool. Young Children, 67(2), 20-26.

Symonds, J. E., \& Gorard, S. (2010). Death of mixed methods? Or the rebirth of research as a craft, Evaluation \& Research in Education, 23(2), 121-136.

Şenel, T., ve Aslan, O. (2014). Okul öncesi öğretmen adaylarının bilim ve bilim insanı kavramlarına ilişkin metaforik algıları.Mersin Üniversitesi Eğitim Fakültesi Dergisi, 10(2), 76-95.

Thulin, S., \& Redfors, A. (2017). Student preschool teachers' experiences of science and its role in preschool. Early Childhood Education Journal, 45(4), 509-520.

Tuttle, N., Mentzer, G. A., Strickler, L., Bloomquist, D., Hapgood, S., Molitor, S., Kaderavek, J., \& Czerniak, C. M. (2017). Exploring how families do science together: adult-child interactions at community science events. School Science and Mathematics, 117(5), 175-182.

Türkoğlu, A. Y. (2017). Okul öncesi fen eğitiminde model kullanımı. Kastamonu Ĕ̆itim Dergisi, 25(5), 1995-2006.

Uğraş, H., Uğraş, M., ve Çil, M. (2013). Okulöncesi öğretmenlerinin fen eğitimine karş1 tutumlarının ve fen etkinliklerine ilişkin yeterliliklerinin incelenmesi. Bittis Eren Üniversitesi Fen Bilimleri Dergisi, 2(1), 44-50.

Uysal, H., Tepetaş Cengiz, Ş., Güçhan Özgül, S., Akar Gençer, A., ve Akman, B. (2016). Okul öncesi öğretmenlerinin bilim defterlerine ilişkin görüşlerinin incelenmesi. Necatibey Ĕgitim Fakültesi Elektronik Fen ve Matematik Ĕ̈itimi Dergisi, 10(1), 85-106.

Ültay E., ve Can, M. (2015). Okul öncesi öğretmen adaylarının 1sı ve sıcaklık konusundaki kavramsal bilgilerinin belirlenmesi. Karadeniz Sosyal Bilimler Dergisi, 7(2),. Retrieved from http://dergipark.gov.tr/ksbd/issue/16219/169876 
Ünal, M., ve Akman, B. (2013). Investigation of preschool teachers' attitudes towards science teaching (Sample of Malatya City). The Journal of Academic Social Sciences Studies, 6(3), 785-798.

Ünal, M., ve Aral, N. (2014). Fen eğitiminde problem çözme ölçeğinin geliştirilmesi: geçerlik ve güvenirlik çalışmaları. Ĕ̈itim ve Bilim, 39(176), 267-278.

Vosniadou, S., \& Brewer, W. (1992). Mental models of the earth: A study of the conceptual change in childhood. Cognitive Psychology, 24, 535-585.

Wang, J., Werner-Avidon, M., Newton, L., Randol, S., Smith, B., \& Walker, G. (2013). Ingenuity in action: Connecting tinkering to engineering design processes. Journal of Pre-College Engineering Education Research, 3(1).

Yalçın, F. A., Yalçın, M., Bozan, S., ve Gecikli, E. (2016). Okul öncesi öğretmenlerinin çevre eğitimiyle ilgili görüşleri. Bayburt Eğitim Fakültesi Dergisi, 11(2), 633-642.

Yıldırım, G., ve Özyılmaz Akamca, G. (2017). The effect of outdoor learning activities on the development of preschool children. South African Journal of Education, 37(2), 1-10.

Yurt, Ö., ve Ömeroğlu, E. (2013). Araştırmaya dayalı bilim eğitim programının 60-72 aylık çocukların bilim öğrenmelerine etkisi. Bayburt Üniversitesi Eğitim Fakültesi, (VIII)I, 135-159. 